\title{
A Retrospective Environmental Assessment of the Natural Heritage of Dal Lake for Prospective Implication Scenarios
}

\author{
Umar Nazir Bhat*and Anisa B. Khan \\ Department of Ecology and Environmental Sciences, Pondicherry University, Puducherry, India- 605014. \\ Email: unbspn@gmail.com
}

\begin{abstract}
Monitoring at 30 sampling sites of Dal Lake is carried out to assess its spatial-temporal heterogeneity under human pressures. $\mathrm{P}$ surpass critical eutrophic index $\left(\leqslant 0.05 \mathrm{mgL}^{-1}\right)$ while nitrate-N persist beneath it $\left(\leqslant 0.5 \mathrm{mgL}^{-1}\right)$. Semi-drainage hydrology recuperates basin volume. Autotrophic assimilation and biocalcification episodes drop conductivity. Anionic prevalence of $\mathrm{HCO}_{3}$ and $\mathrm{Cl}^{-}$exist along $\mathrm{Ca}>\mathrm{Mg}>\mathrm{Na}>\mathrm{K}$ cationic progression. Autochthonous sediment $\mathrm{OM}$ at typical $<10 \mathrm{C} / \mathrm{N}$ is the conventional nutrient source. Higher temperature and lower N:P ratio during summer develop $\mathrm{P}$ internal loading process. $\mathrm{Cr}, \mathrm{Ni}$ and $\mathrm{Zn}$ exceed the sediment quality guidelines. $\mathrm{OM}$ enriched sediments and calcite co-precipitation curtails PTE mobility. Biomass parameters establish similar variations except species turn-over. OM immobilizes nutrients and OC provisions denitrification. Dal Lake exposed to anthro-urban intensification depends on comprehensive management interventions like National Plan for Conservation of Aquatic Ecosystems vital for insitu leniency control and lake-front improvement.
\end{abstract}

Keywords: Bioconcentration, compartmentalization, eutrophication, macrophytes, remediation, sewage.

\section{Introduction}

Water- the elixir of life founds a vital constituent of biota and has foremost expanse (> 70\%) over the Blue Planet. Yet, out of the entire estimated global water assets approximately 3\% only encompasses the fresh water. This limited stock becomes more indispensable when its major proportion of $99.7 \%$ is accounted as unavailable-water locked up in cryosphere or in deep sub-surface water pools while the meager remainder of $113 \times 10^{3} \mathrm{Km}^{3}$ exists as accessible surface fresh water [1]. But lakes globally assume the paramount $(87 \%)$ of the $0.3 \%$ surface waters. Lakes feature as prominent standing water bodies over roughly $1.8 \%$ of the land area covering 2.5 million $\mathrm{Km}^{2}$ and containing about $2.8 \times 10^{5} \mathrm{Km}^{3}$ of water [2]. Lakes aren't mere water storages but perform complex dynamic hydrological, biogeochemical, geomorphological, climatic and other ecological functions. These aquatic ecosystems provide crucial services like: (a) Resource provision of water, food, fiber, fuel, fish, medicine, ornaments, and the like; (b) Regulating services of flood cum drought mitigation, self-purification, climate mediation, food-web linkages, aquatic biodiversity, ecotone buffer capacity, navigation routes, etc.; (c) Cultural services of socio-economic, aesthetic, religious, spiritual, recreational, historic and educational values; (d) Supporting services of heat energy budget, geological formation, nutrient cycling, water cycle, habitats and gene pool and primary production [3].

The state of Jammu and Kashmir (J\&K) set in the north-west Himalayan biogeographic zone of India exists at an altitude $\geqslant 1500 \mathrm{~m}$ a.s.l. The asymmetrical vale of Kashmir measuring about $15948 \mathrm{Km}^{2}$ has the latitudinal expanse of $33^{\circ} 20^{\prime}$ to $34^{\circ} 54^{\prime} \mathrm{N}$ while its longitudinal extent is from $73^{\circ} 55^{\prime}$ to $75^{\circ} 35^{\prime} \mathrm{E}$. The temperate climatic valley has about $64 \%$ mountainous physiography with the Great Himalayas in its North and Pir Panjal range in its South. Kashmir is proprietary of a collection of natural lacustrine water bodies upholding paramount ecological, cultural, historical and socioeconomic significance. The estimated geographic area occupied by lakes in J\&K is 13762 ha that approximates to $3.52 \%$ of all its aquatic ecosystems [4]. The lake typology of Kashmir with varying origin, elevational location and biotic composition include: (i) Glacial Lakes situated in snowline vicinity; (ii) Pine- Forest Lakes in the midst of timberline and (iii) Valley Lakes located across 1580 to $1600 \mathrm{~m}$ a.s.l. altitude [5]. These lakes harbour diverse gene-pool, act as indispensable source of food, fodder and manure and are sites of invaluable 
aesthetic, tourism and recreational value [6]. Lakes are one of the utmost essential natural resources of our State. Apart from being valued natural habitats for a number of flora and fauma, they act as the life line for various communities of our state. No systematic scientific study mechanism for monitoring, planning and management of these lakes is in place as more than $90 \%$ of them remain neglected altogether till date. The very existence of the lacustrine water bodies is under continuously intensifying multiple stressors of nutrient loading, siltation, waste disposal, sewerage and agro-chemical residue receivers, expanding floating-garden area, encroachment, blockade and narrowing of drainage channels, hydrological alterations, catchment perturbations and so on [7].

\section{Study Area and Methods}

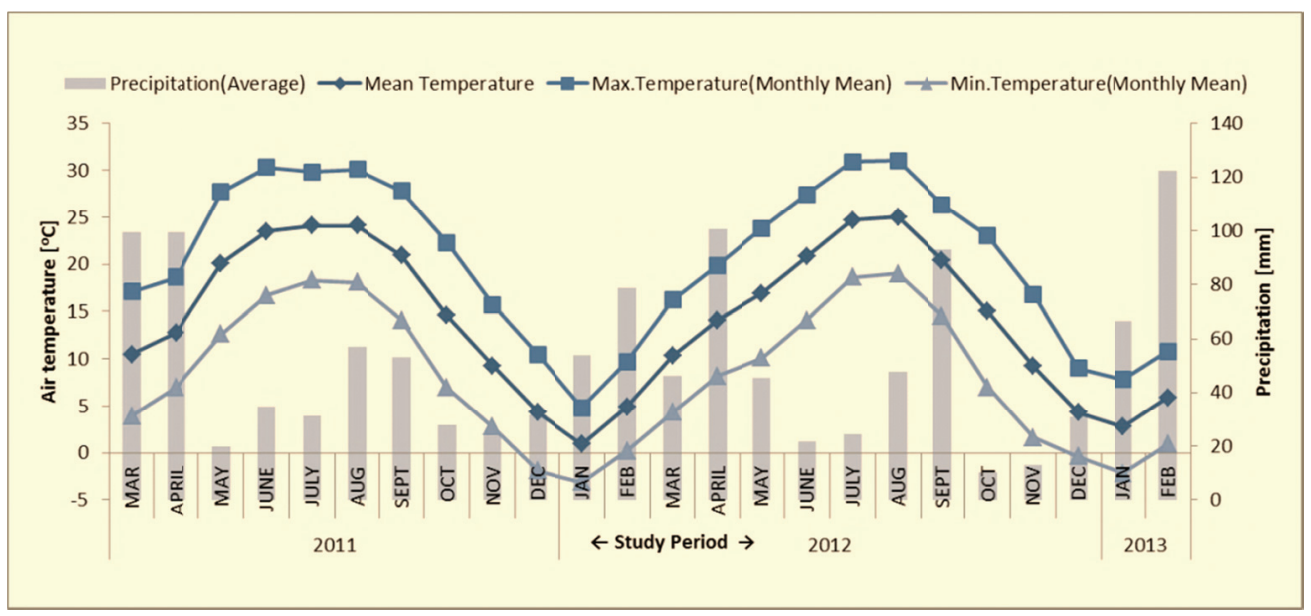

Figure 1. Climate profile of Srinagar 2011 - 2013 (Data source: India Meteorological Department).

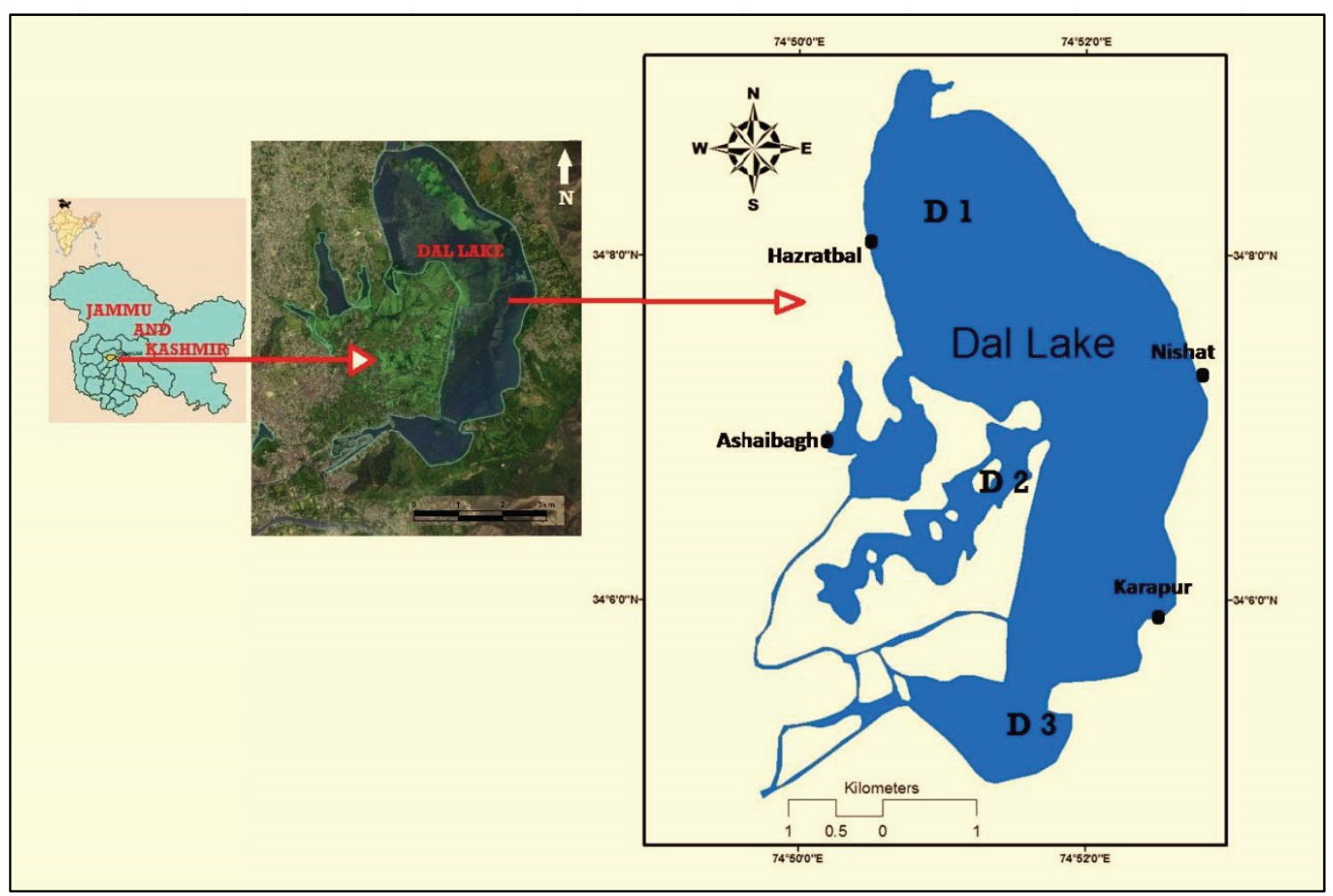

Figure 2. Location of study area (Dal Lake). 
Lakes' are conventional natural laboratories to study numerous hydro-geochemical and ecological processes. Eutrophication predominantly impairs surface water quality [8] and [9]. A rational identification of undesirable pollution levels and appropriate desirable remediation targets is possible if assessments involving health risk [10] and ecological impact [11] are practiced. The summer capital (Srinagar) of J\&K abides a lake area cover of 2194 ha equivalent to $21.76 \%$ of its total wetland area. The city of Srinagar $\left(33^{\circ} 59^{\prime} 14^{\prime \prime}-34^{\circ} 12^{\prime} 37^{\prime \prime} \mathrm{N}\right.$ latitudes and $74^{\circ} 41^{\prime} 06^{\prime \prime}-74^{\circ} 57^{\prime} 27^{\prime \prime}$ E longitudes) sited on the banks of the Jhelum (Vyeth) spreads across the plains of Kashmir vale. It has a moderate physiography $\geqslant 1580 \mathrm{~m}$ a.s.l. representing hill topography. The general climatic conditions resemble the sub-Mediterranean characterized by year-long precipitation events except a few summer and autumn dry periods, besides, both seasonal and diurnal extremes of temperature. During the course of study, the maximum, mean and minimum monthly temperatures $\left({ }^{\circ} \mathrm{C}\right)$ and average rainfall $(\mathrm{mm})$ at Srinagar is illustrated in Fig. 1. The emphasis of current limnological research is a relatively managed fluvial urban valley lake namely Dal lake (Fig. 2). The geographical position of Dal lake is north-east of Srinagar city at $1587 \mathrm{~m}$ a.s.l. altitude occupying the coordinates of $34^{\circ} 04^{\prime} \mathrm{N}$ to $34^{\circ} 09^{\prime} \mathrm{N}$ and $74^{\circ} 49^{\prime} \mathrm{E}$ to $74^{\circ} 52^{\prime} \mathrm{E}$ [4]. It is a tetra-basined ox-bow type lake formed by meandering course of river Jhelum. Its focal feeding source is a perennial Dachigam brook (splitted into 3 rivulets of Telbal, Pishpu and Meerakshah) and several lake-bed springs, however, the main exit discharges via Dalgate into the Jhelum. Indian Institute of Technology (IIT), Roorkee designates an area of $337 \mathrm{~km}^{2}$ as its catchment while stocking a water volume of $15 \times 10^{6} \mathrm{~m}^{3}$. The 2007 satellite imagery database of Lakes and Waterways Development Authority (LWDA) reveals its total area as $24.6 \mathrm{Km}^{2}$ with an open water expanse of $15.41 \mathrm{Km}^{2}$ and the remaining occupied by floating gardens, emergent vegetation zone, house boats and human settlement area. A recent assessment intimates the open water spread restricted to just $10.5 \mathrm{Km}^{2}$ [12]. The mean depth averages to $<3 \mathrm{~m}$ while the maximum depth equals $6 \mathrm{~m}$. Dal is an urban recreational and tourism site having a significant socioeconomic association and reliance. As a consequence of continuous pressure from $\sim 5$ lac population dwelling in and around the lake, it has degraded to eutrophic state [13]. Some of the problems and threats leading to lakes' deterioration [14] and [15] include nutrient enrichment, unsustainable tourist inflow, peripheral land use, unplanned urbanization, sewage and solid waste recipient, volume reduction by siltation, floating gardens for commercial vegetable production using pesticides and fertilizers, congestion of outflow channels, encroachment, weed proliferation, besides administrative bottle-necks in the form of infrastructural and staff shortage for effective execution of conservation projects. The Dal also receives point sewage effluents from 3 commissioned STP's [16] of

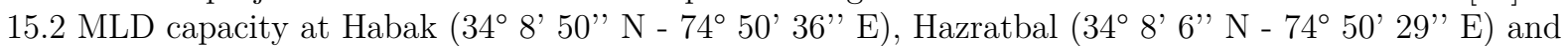
Laam (34ㄱ' $42^{\prime}$ ' N - $\left.74^{\circ} 52^{\prime} 36^{\prime \prime} \mathrm{E}\right)$.

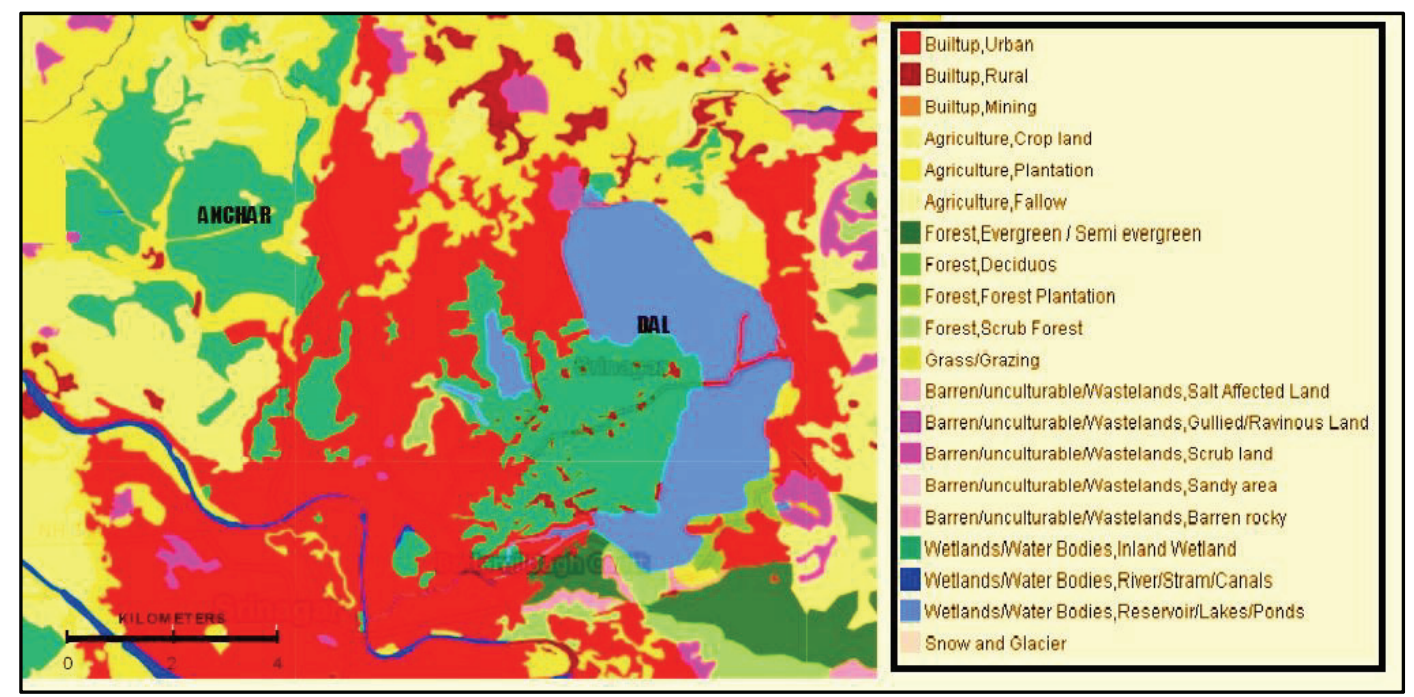

Figure 3. Visualisation of land- cover/use for study site catchment (Source: NRSC/ISRO- Bhuvan). 
A primary probe indicates the Dal as impartially managed-lake evident from its physical appearance and open-water surface area. However, the lake is gradually being overwhelmed by urban and agricultural conversions as apparent from the roseate expanses of satellite imagery (Fig. 3). The interannual survey, sample collection and hydrobiochemical study of the lake is based on its 3 zones. The three locations (Table 1) labelled as D1, D2 and D3 were further split into 10 sampling stations each (Fig. 2) inorder to obtain composite representative samples in triplicate for superior precision. The zone assortment criterion applied here represents the distinct spatial features within the lake. D1 neighborhood is contributed with strategic inlet and sewage treatment plant (STP) discharges; D2 typifies the floating garden area; and D3 adjacent to the outlet is a hotel and house-boat sector. The pictorial glimpses of the select sites are provided in Plate I.

Table 1. Coordinates of sampling locations.

\begin{tabular}{ccccccccc}
\hline SITE & \multicolumn{3}{c}{ LATITUDE } & \multicolumn{3}{c}{ LONGITUDE } \\
\hline D1 & $34^{\circ}$ & $8^{\prime}$ & $35^{\prime \prime}$ & $\mathrm{N}$ & $74^{\circ}$ & $51^{\prime}$ & $17^{\prime \prime}$ & $\mathrm{E}$ \\
D2 & $34^{\circ}$ & $7^{\prime}$ & $56^{\prime \prime}$ & $\mathrm{N}$ & $74^{\circ}$ & $51^{\prime}$ & $44^{\prime \prime}$ & $\mathrm{E}$ \\
D3 & $34^{\circ}$ & $5^{\prime}$ & $53^{\prime \prime}$ & $\mathrm{N}$ & $74^{\circ}$ & $51^{\prime}$ & $18^{\prime \prime}$ & $\mathrm{E}$ \\
\hline
\end{tabular}

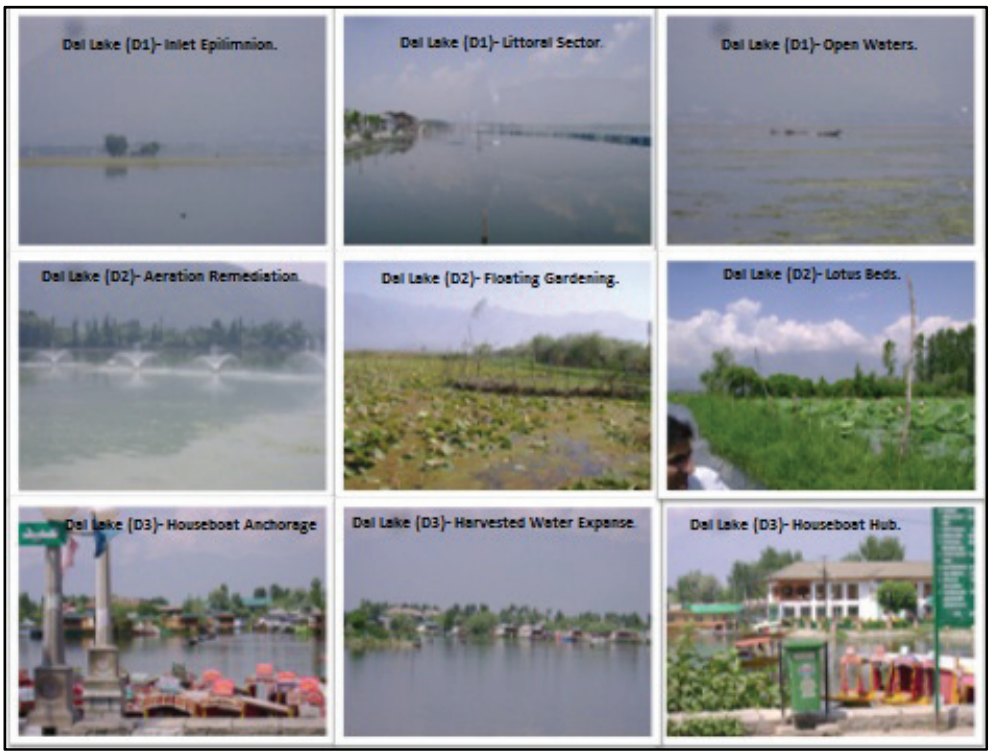

Plate I. Pictorial glimpses of the study site.

The appraisal, sample gathering and limnological analysis of water, sediment and macrophytes from selected sites of the lake were carried out from March, 2011 to February, 2013. For the purpose of contemporary research, water, sediment and macrophytes are collected simultaneously at the same sampling locations. The water samples were analysed for temperature, $\mathrm{pH}$, conductivity, bicarbonates, chloride, calcium, magnesium, sodium, potassium, nitrate nitrogen and total phosphorus on monthly basis while trace elements of $\mathrm{Al}, \mathrm{As}, \mathrm{Cd}, \mathrm{Co}, \mathrm{Cr}, \mathrm{Cu}, \mathrm{Fe}, \mathrm{Hg}, \mathrm{Mn}, \mathrm{Ni}, \mathrm{Pb}, \mathrm{Se}$, Sn and Zn were measured for spring, summer and winter seasons. The collection, preservation, preparation, storage and estimation of water samples follow standard methods of [17], [18], [19], [20], [21] and [22]. The sediment analysis includes $\mathrm{H}$-ion concentration, electrical conductivity, bicarbonates, organic-C, organic matter, total-N, $\mathrm{C} / \mathrm{N}$ ratio, elemental composition of $\mathrm{Ca}, \mathrm{Cl}, \mathrm{K}, \mathrm{Mg}, \mathrm{Na}, \mathrm{P}, \mathrm{S}, \mathrm{Si}$ and the given trace elements for each season. $\mathrm{pH}$ and electrical conductivity are determined immediately within 6 hours of sampling and the rest of the parameters are scheduled on oven dried samples following standard recommended methods from [23], [24], [25] and [26]. The biological component (macrophytes) employed in the study is of prominence amongst the lake-community structure and function. The select species (Plate II) chosen from emergent, free-floating, rooted-floating and submerged categories include Myriophyllum aquaticum, 


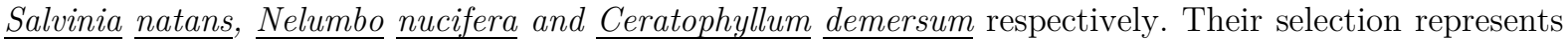
omnipresent abundance at each sampling location besides being high biomass yielding, eutrophication tolerant and hyperaccumulators. The preferred producer species are recognized while referring to standard taxonomic scheme of [27], [28] and [29]. Over again, the macrophytic biomass was analysed for total chlorophyll content, biomass, productivity, specific growth rate, mineral composition $(\mathrm{Ca}, \mathrm{Cl}, \mathrm{K}$, Mg, N, Na, P, S, Si) and the trace elements during their sprouting (sp.)- (March to May), peak growth (pg.)- (June to October) and senescence (sn.)- (November to February) phases. Due consideration is given to collect and preserve the sub-samples of water, sediment and hydrophytes from the identical spot. For plant and sediment samples various parametric evaluations are performed following [23], [24] and [30]. The multi-elemental quantification of $\mathrm{Ca}, \mathrm{Cl}, \mathrm{K}, \mathrm{Mg}, \mathrm{Na}, \mathrm{P}, \mathrm{S}$ and $\mathrm{Si}$ in sediments and plant biomass is performed using Wavelength Dispersive X-ray Fluorescence Spectrometer (WD-XRF) at Central Instrumentation Facility (CIF), Pondicherry University. However, the trace elements in all samples were determined at Sophisticated Analytical Instrument Facility (SAIF) IITM, Chennai using ICP-OES (Perkin Elmer Optima 5300 DV) instrument. Further, the descriptive and illustrative statistical analysis is performed using MS-Excel 2010, Origin 8.5, PAST 3 and SPSS 21.

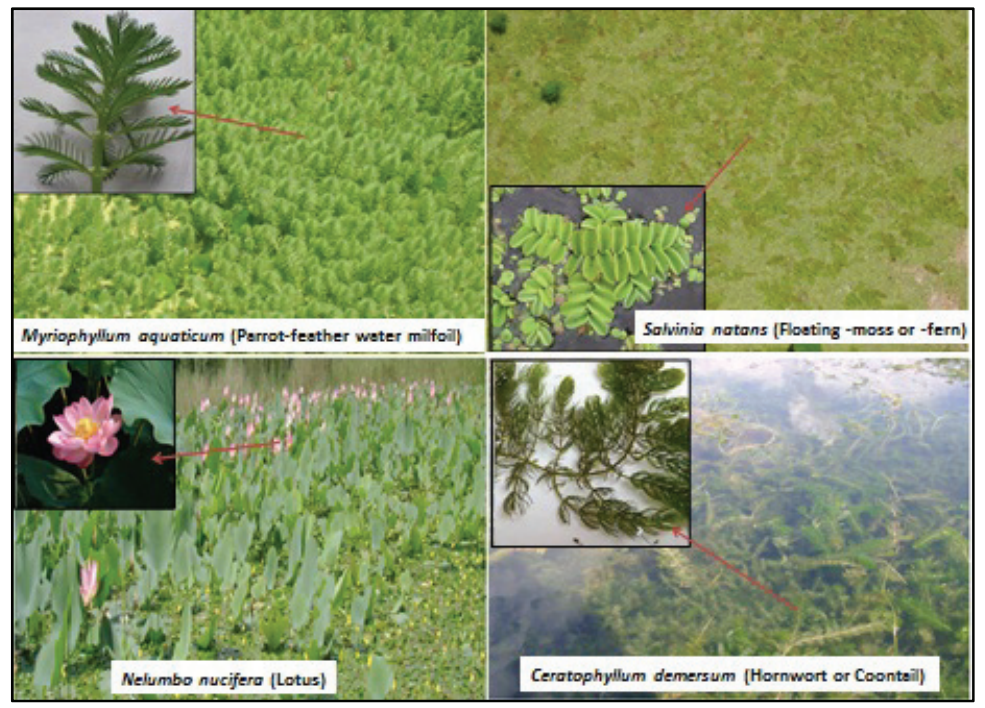

Plate II. Analysed predominant emergent, free-floating, rooted-floating and submerged macrophytes.

\section{Results}

(a) Epilimnion: The spatial (Fig. 4) and temporal (Fig. 5) limnochemical sum up of water variables present a useful depiction of lake circumstance and eutrophic stage. The documented surface water temperature $\left({ }^{\circ} \mathrm{C}\right)$ validates the meteorological intervals of the study area. It ranges between 5 to $30^{\circ} \mathrm{C}$ time-wise with position averages of $18.1 \pm 7.4$ at $\mathrm{D} 1,18.1 \pm 7.0$ at $\mathrm{D} 2$ and $18.5 \pm 7.0{ }^{\circ} \mathrm{C}$ at D3. The temperature variance between sites $(\mathrm{F}=.013$ and $\mathrm{p}>0.05)$ is insignificant, however, seasonal variation is significant $(\mathrm{F}=1.39$ and $\mathrm{p}<0.05)$. The $\mathrm{pH}$ findings altered between 7.2 and 8.6 denoting alkaline waters with reasonably higher summer peaks. The site-wise averages are $8.2 \pm 0.43,8.1 \pm 0.43$ and 8.0 \pm 0.41. ANOVA for $\mathrm{pH}$ has significance between seasons $(\mathrm{F}=9.782$ and $\mathrm{p}<0.05)$ as well. Conductivity examinations demonstrated a drop towards the spring and summer months apparently due to dilution and ion uptake by vegetation existent in the water-column. The conductivity range witnessed has lowermost value of $100 \mu \mathrm{Scm}^{-1}$ and maximum of $565 \mu \mathrm{Scm}^{-1}$ besides having mean site values of $294.7 \pm 113.83,266.8 \pm 100.87$ and $271.3 \pm 87.60 \mu \mathrm{Scm}^{-1}$. Seasonal ANOVA of conductivity is more substantial $(\mathrm{F}=7.829$ and $\mathrm{p}<0.05)$ than lake contrasts $(\mathrm{F}=4.526$ and $\mathrm{p}<0.05)$. The HCO3 concentration ranges from 60 to $218 \mathrm{mgL}^{-1}$ and at the chosen sites average to $105.2 \pm 24.93,105.0 \pm 25.89$ and $105.7 \pm 27.95 \mathrm{mgL}^{-1}$ respectively. Bicarbonates register noteworthy seasonal variation $(\mathrm{F}=35.431$ and $\mathrm{p}<0.05)$ only. The chloride $\left(\mathrm{mgL}^{-1}\right)$, calcium $\left(\mathrm{mgL}^{-1}\right)$, magnesium $\left(\mathrm{mgL}^{-1}\right)$, sodium $\left(\mathrm{mgL}^{-1}\right)$, potassium $\left(\mathrm{mgL}^{-1}\right)$, nitrate nitrogen $\left(\mu \mathrm{gL}^{-1}\right)$ and total phosphorus $\left(\mu \mathrm{gL}^{-1}\right)$ although differ in being as major $(>5$ 
$\mathrm{mgL}^{-1}$ ) or minor (0.01 to $10 \mathrm{mgL}^{-1}$ ) elements but illustrate virtually an undistinguishable prospect of withdrawal through crowning growth periods of macrophytes and again revive in the medium after their senescence. The ANOVA classifies the variables as significantly changeable between the sites $(\mathrm{p}<0.05)$ except Ca but insignificantly varying between seasons ( $\mathrm{p}>0.05$ ) except $\mathrm{Ca}, \mathrm{Mg}$ and $\mathrm{K}$. Their corresponding chronological range and site averages are tabularized in Table 2.

Table 2. Range and mean concentration of major and minor nutrients in water at the selected sites.

\begin{tabular}{ccccc}
\hline ELEMENT & RANGE & D1 & D2 & D3 \\
\hline $\mathrm{Cl}\left(\mathrm{mgL}^{-1}\right)$ & $11.6-28.5$ & $17.1 \pm 3.06$ & $21.4 \pm 3.07$ & $16.3 \pm 1.44$ \\
$\mathrm{Ca}\left(\mathrm{mgL}^{-1}\right)$ & $38-101$ & $75.1 \pm 17.34$ & $75.6 \pm 17.09$ & $71.4 \pm 16.2$ \\
$\mathrm{Mg}\left(\mathrm{mgL}^{-1}\right)$ & $16.8-25$ & $20.6 \pm 1.36$ & $22.4 \pm 1.59$ & $19.8 \pm 1.05$ \\
$\mathrm{Na}\left(\mathrm{mgL}^{-1}\right)$ & $7.5-12.7$ & $8.8 \pm 0.47$ & $10.0 \pm 0.72$ & $8.9 \pm 0.52$ \\
$\mathrm{~K}\left(\mathrm{mgL}^{-1}\right)$ & $2.6-5$ & $3.9 \pm 0.45$ & $4.4 \pm 0.49$ & $3.6 \pm 0.42$ \\
$\mathrm{NO}_{3}-\mathrm{N}\left(\mathrm{\mu gL}^{-1}\right)$ & $220-555$ & $261.4 \pm 25.1$ & $338.4 \pm 57.4$ & $279.3 \pm 23.5$ \\
$\mathrm{P}\left(\mathrm{\mu gL}^{-1}\right)$ & $110-289$ & $150.67 \pm 13.70$ & $150.67 \pm 18.46$ & $143.42 \pm 12.66$ \\
\hline
\end{tabular}

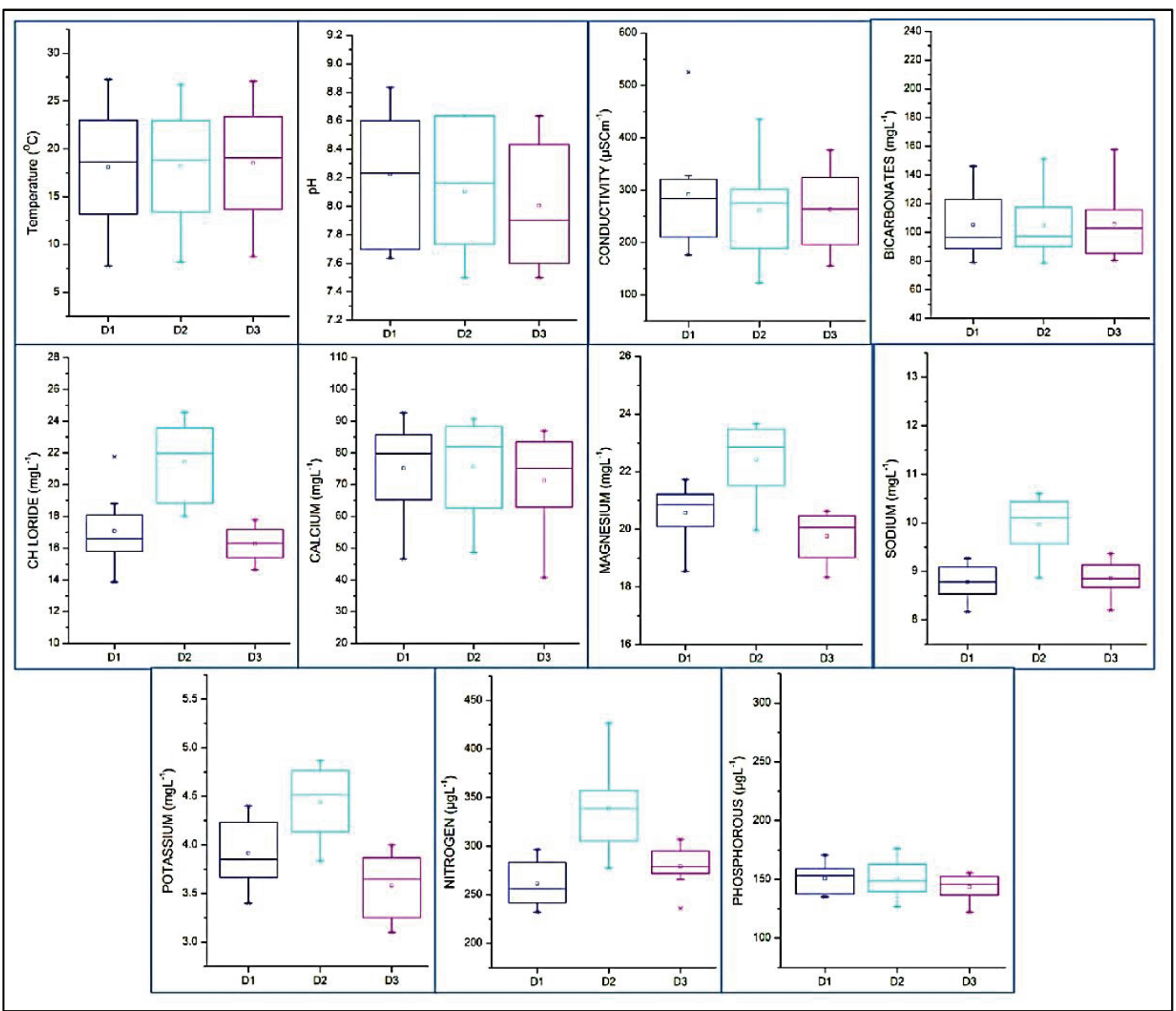

Figure 4. Quantitative spatial variation in water quality variables. 


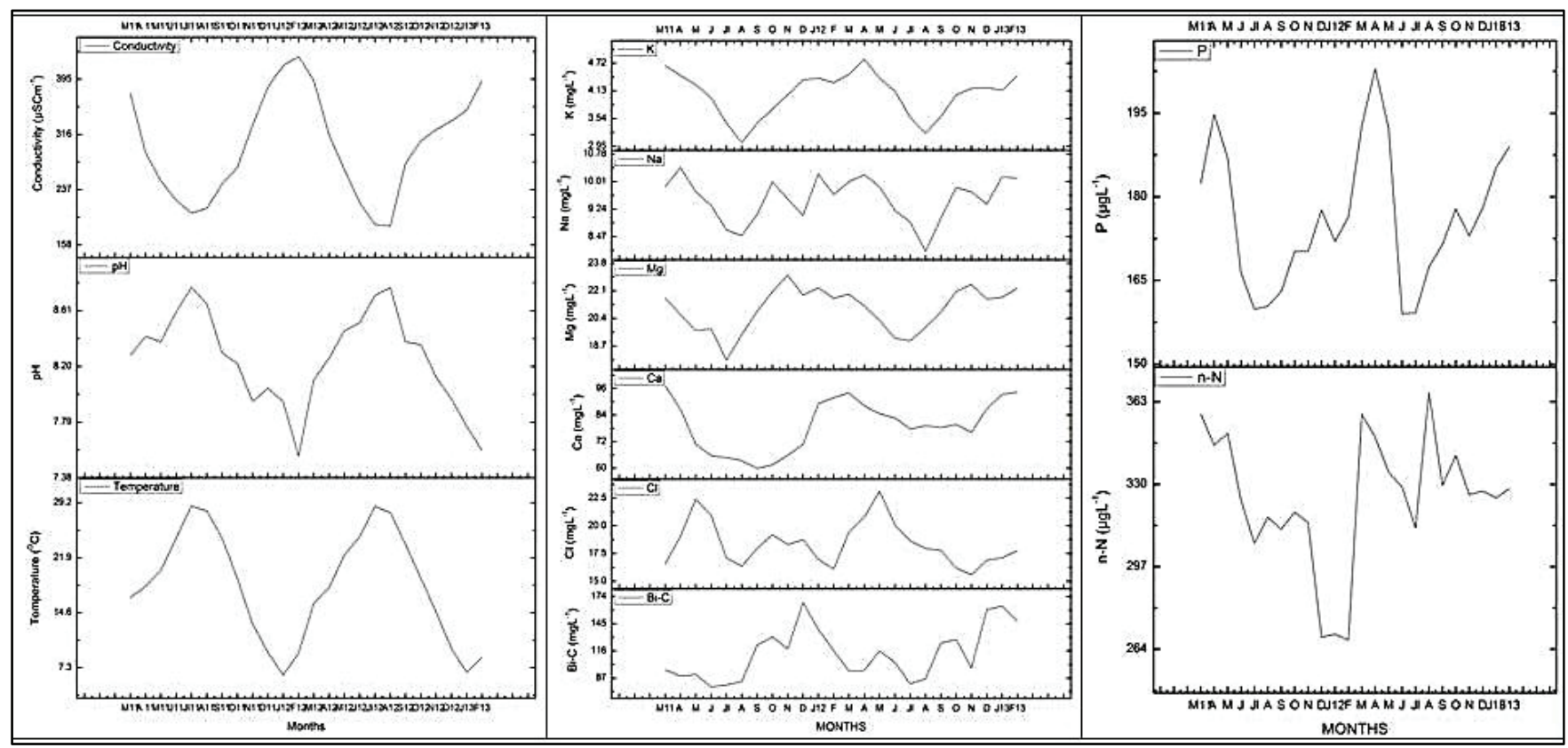

Figure 5. Temporal fluctuations in epilimnion variables.

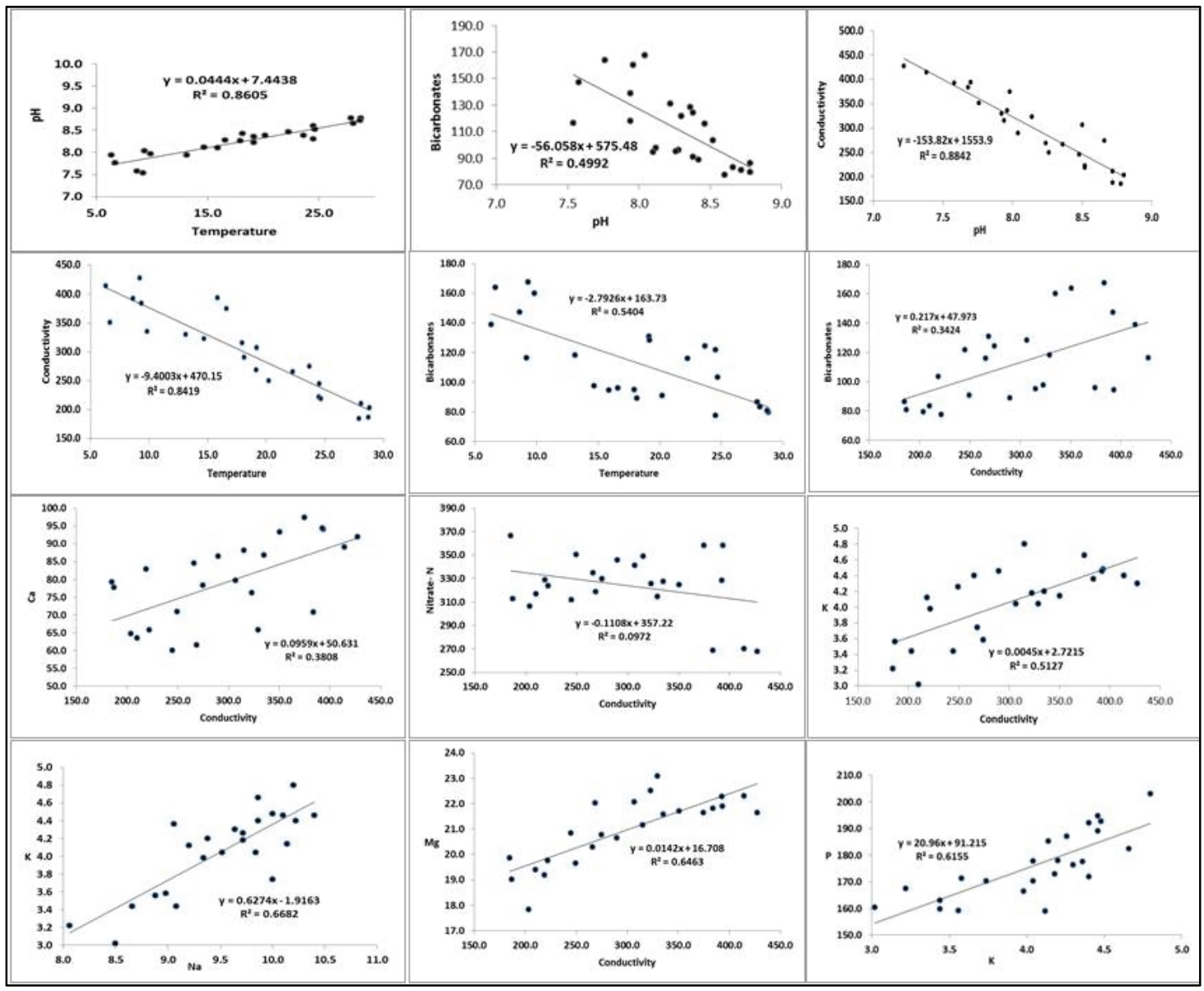

Figure 6. Regression analysis of water variables. 
Table 3. Average seasonal total trace elements in lake waters $\left(\mathrm{mgL}^{-1}\right)$.

\begin{tabular}{|c|c|c|c|c|c|c|c|c|c|c|c|c|c|c|c|}
\hline SITE & SEASON & $\mathrm{Al}$ & As & $\mathrm{Cd}$ & $\mathrm{Co}$ & $\mathrm{Cr}$ & $\mathrm{Cu}$ & $\mathrm{Fe}$ & $\mathrm{Hg}$ & $\mathrm{Mn}$ & $\mathrm{Ni}$ & $\mathrm{Pb}$ & $\mathrm{Se}$ & $\mathrm{Sn}$ & $\mathrm{Zn}$ \\
\hline \multirow{3}{*}{ D1 } & SPRING & 1.2 & $\mathrm{BDL}$ & $\mathrm{BDL}$ & $\mathrm{BDL}$ & 0.041 & 0.012 & 2.96 & $\mathrm{BDL}$ & 1.33 & 0.05 & BDL & $\mathrm{BDL}$ & 0.29 & 26.2 \\
\hline & SUMMER & 0.9093 & 0.013 & 0.003 & 0.005 & 0.035 & 0.052 & 9.133 & BDL & 0.343 & 0.025 & 0.074 & 0.005 & 0.239 & 7.385 \\
\hline & WINTER & 1.16 & $\mathrm{BDL}$ & $\mathrm{BDL}$ & BDL & 0.011 & 0.01 & 1.97 & BDL & 0.5 & BDL & 0.03 & 0.004 & BDL & 21.6 \\
\hline \multirow{3}{*}{ D2 } & SPRING & BDL & BDL & BDL & BDL & 0.019 & BDL & 2.43 & BDL & 0.31 & BDL & BDL & BDL & BDL & 13.3 \\
\hline & SUMMER & 0.9735 & 0.009 & 0.003 & 0.002 & 0.038 & 0.042 & 3.328 & BDL & 0.218 & 0.024 & 0.083 & 0.014 & 0.171 & 15.51 \\
\hline & WINTER & 0.2 & $\mathrm{BDL}$ & BDL & BDL & BDL & BDL & 6.1 & BDL & 1.25 & BDL & BDL & $\mathrm{BDL}$ & 0.11 & 10 \\
\hline \multirow{3}{*}{ D3 } & SPRING & 0.82 & $\mathrm{BDL}$ & BDL & BDL & 0.027 & 0.051 & 4.76 & BDL & 0.14 & BDL & BDL & 0.01 & BDL & 17.6 \\
\hline & SUMMER & 1.361 & 0.011 & 0.003 & 0.004 & 0.038 & 0.097 & 10.15 & BDL & 0.381 & 0.025 & 0.085 & 0.016 & 0.236 & 22.22 \\
\hline & WINTER & 1.41 & 0.005 & 0.003 & 0.002 & 0.026 & 0.08 & 9.97 & $\mathrm{BDL}$ & 0.27 & 0.019 & 0.12 & $\mathrm{BDL}$ & 0.21 & 30.4 \\
\hline \multicolumn{2}{|c|}{ AVERAGE } & 1.678 & 0.012 & 0.003 & 0.010 & 0.040 & 0.133 & 5.602 & BDL & 0.610 & 0.034 & 0.090 & 0.010 & 0.191 & 18.520 \\
\hline \multicolumn{2}{|c|}{ STANDARD DEVIATION } & 1.322 & 0.003 & 0.001 & 0.007 & 0.023 & 0.108 & 2.741 & BDL & 0.438 & 0.018 & 0.028 & 0.005 & 0.053 & 7.118 \\
\hline \multicolumn{2}{|c|}{ MINIMUM } & 0.2 & 0.005 & 0.002 & 0.002 & 0.01 & 0.01 & 1.97 & $\mathrm{BDL}$ & 0.1 & 0.016 & 0.03 & 0.003 & 0.1 & 7.385 \\
\hline \multicolumn{2}{|c|}{ MAXIMUM } & 4.516 & 0.015 & 0.004 & 0.02 & 0.09 & 0.33 & 10.15 & BDL & 1.512 & 0.071 & 0.12 & 0.016 & 0.29 & 30.4 \\
\hline
\end{tabular}

Table 4. Factor loading and variance of PC1, PC2 and PC3.

\begin{tabular}{ccccc}
\hline COMPONENT NUMBER & PARAMETER & $\mathrm{PC} 1$ & $\mathrm{PC} 2$ & $\mathrm{PC} 3$ \\
\hline 1 & CONDUCTIVITY & 0.38 & -0.19 & 0.21 \\
2 & $\mathrm{~K}$ & 0.38 & 0.11 & -0.29 \\
3 & $\mathrm{Na}$ & 0.37 & 0.21 & -0.17 \\
4 & $\mathrm{Mg}$ & 0.34 & -0.04 & -0.32 \\
5 & $\mathrm{Ca}$ & 0.29 & 0.08 & 0.40 \\
6 & $\mathrm{P}$ & 0.29 & 0.34 & 0.38 \\
7 & $\mathrm{HCO}_{3}$ & 0.27 & -0.22 & 0.24 \\
8 & $\mathrm{NO}_{3}-\mathrm{N}$ & 0.20 & 0.48 & 0.15 \\
9 & $\mathrm{Cl}$ & 0.12 & 0.37 & -0.54 \\
10 & $\mathrm{pH}$ & -0.23 & 0.47 & 0.26 \\
11 & $\mathrm{~T}$ & -0.35 & 0.38 & -0.02 \\
\hline \multicolumn{5}{c}{ Eigen value } \\
\% variance & 9341.34 & 4452.90 & 896.66 \\
\hline
\end{tabular}

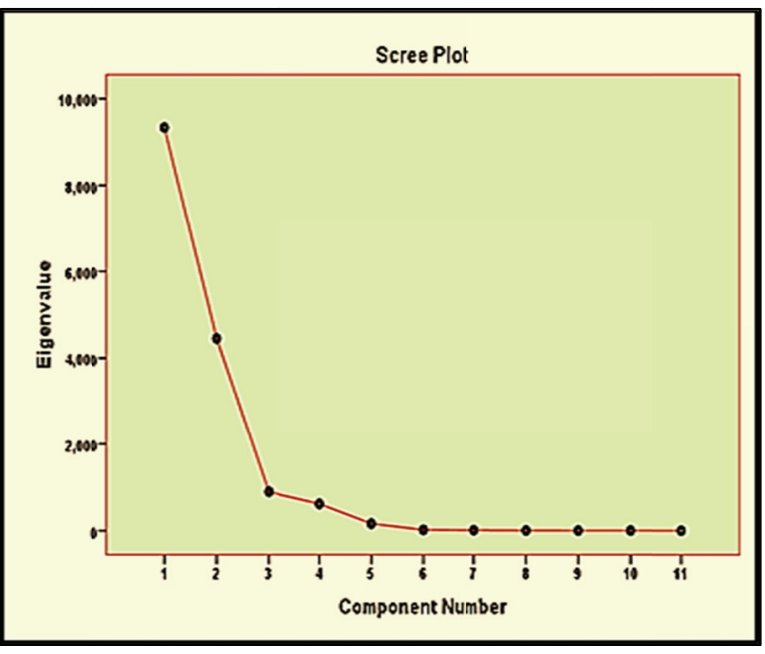

Figure 7. Scree plot for the water parameters. 


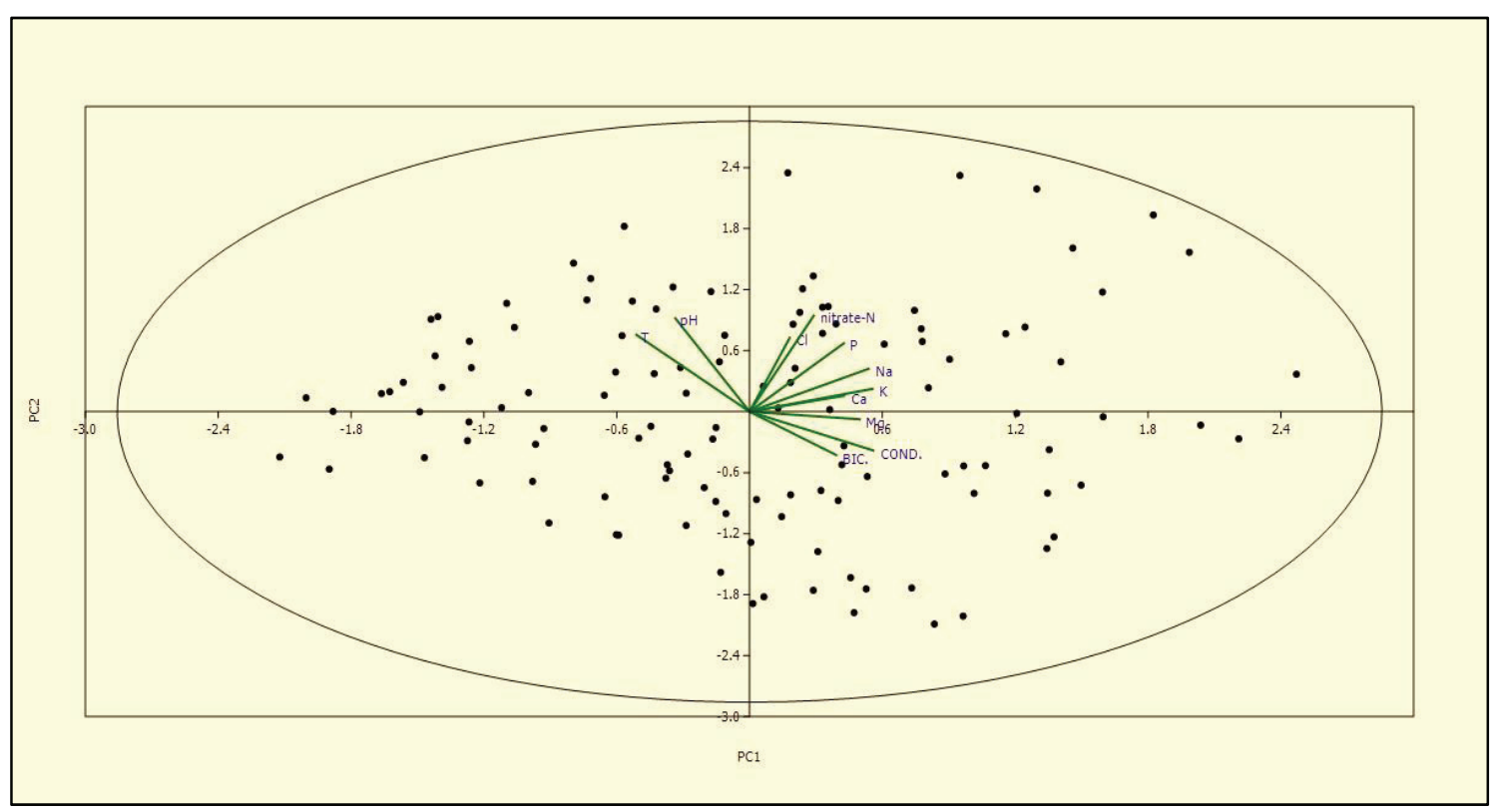

Figure 8. Biplots of PC1, PC2 and PC3 of the water variables (magnitude and sign).

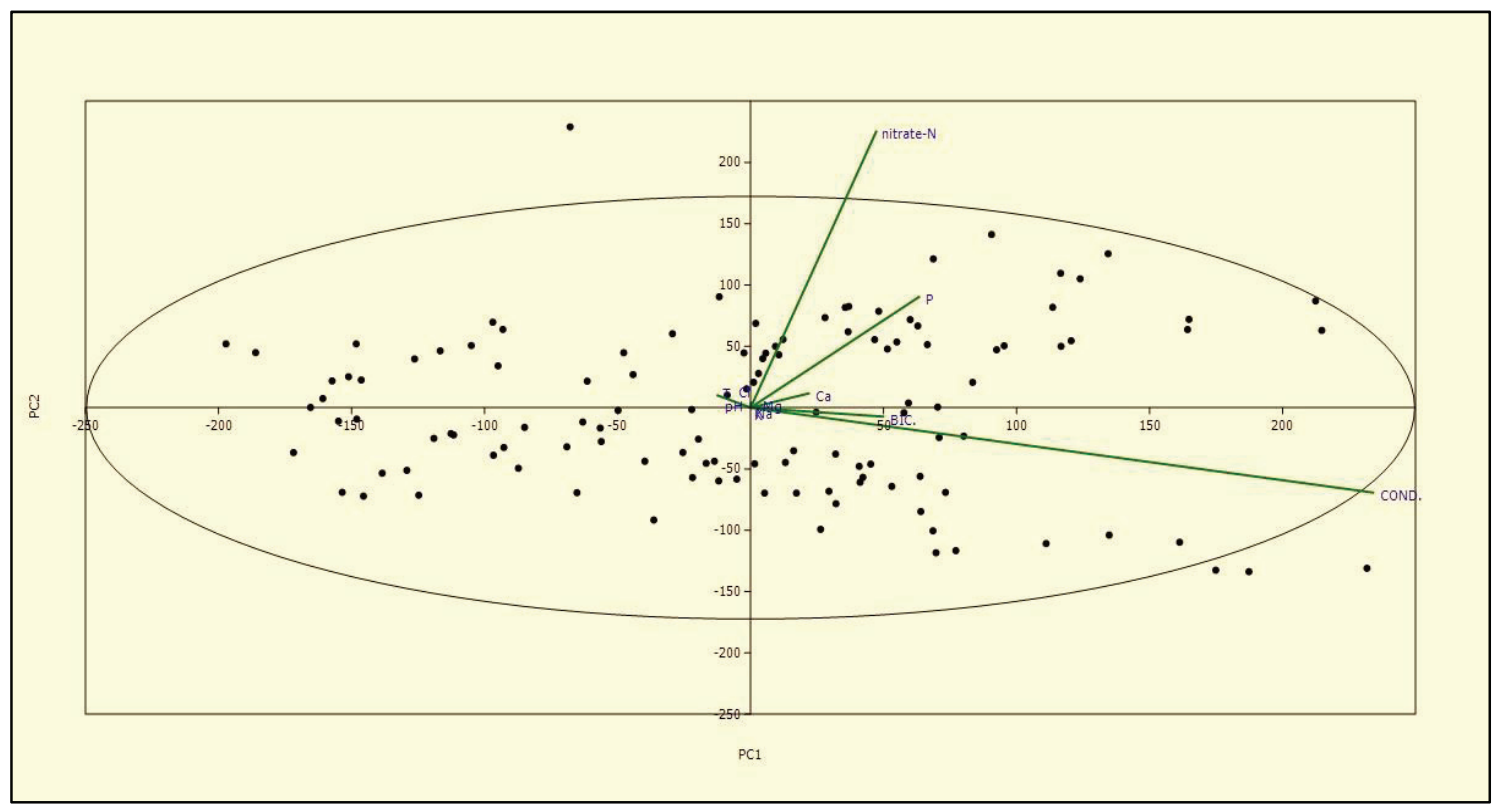

Figure 9. Biplots of PC1, PC2 and PC3 of the water variables (interactions).

The Pearson's correlation coefficients from correlation matrix of water quality variables provide statistically significant relations in case of temperature, $\mathrm{pH}$, bicarbonates and conductivity but nitrate- $\mathrm{N}$ relates to bicarbonates only. Besides, their regression analysis (Fig. 6) gives regression coefficients that depict the intense intra-aqueous interdependence by relating the line of best-fit $\left(\mathrm{R}^{2}\right)$. Table 3 enlists average seasonal total trace element concentration $\left(\mathrm{mgL}^{-1}\right)$ in lake waters at the given sites. The trace elements do not follow any definite seasonal variability $(\mathrm{p}>0.05)$. But ANOVA between sites confirm significance for $\mathrm{Al}(\mathrm{F}=49.14$ and $\mathrm{p}<0.05), \mathrm{Cr}(\mathrm{F}=3.854$ and $\mathrm{p}<0.05), \mathrm{Cu}(\mathrm{F}=28.64$ and $\mathrm{p}<0.05)$ and $\mathrm{Ni}(\mathrm{F}=7.05$ and $\mathrm{p}<0.05)$. Besides, positively significant Pearson correlation grouping at $\mathrm{p}<0.01^{(* *)}$ or $\mathrm{p}$ $<0.05^{(*)}$ occurs for $\mathrm{Al}$ with $\mathrm{Co}^{(* *)}, \mathrm{Cr}^{(* *)}, \mathrm{Cu}^{(* *)}$ and $\mathrm{Ni}^{(*)}$ while As associates with $\mathrm{Cd}^{(* *)}$ and $\mathrm{Ni}^{(* *)}, \mathrm{Cd}$ with $\mathrm{Pb}^{(* *)}$, Co with $\mathrm{Cu}^{(* *)}$ and $\mathrm{Ni}^{(*)}$, $\mathrm{Cr}$ with $\mathrm{Cu}^{(* *)}, \mathrm{Cu}$ with $\mathrm{Ni}^{(*)}$ and $\mathrm{Pb}$ with $\mathrm{Zn}^{(*)}$. PCA prompted 
biplot of the water variables at all select sites collectively visualizes the systematic interaction and variance pattern (between columns and rows, between columns and between rows) of coefficient matrix of PC1, PC2 and PC3 (Table 4). Scree plot description in Fig. 7 defines Eigen value allocation of the components. The magnitude and sign of each variable's contribution to first 2 PC's is visualized in Fig. 8 while their interactions can be extrapolated from Fig. 9. A similarity index of the sites in the form of a dendrogram derived from Hierarchical Cluster Analysis (HCA) of water variables suggests a site specific peculiarity dependence on micro local conditions and perturbation types existing in the lakes. The site cluster arrangement reflects trophic ranking of D2 $>$ D3 $>$ D1. Similarly, the month-wise clustering of the bi-annual observations of the water quality confides seasonal contiguities.

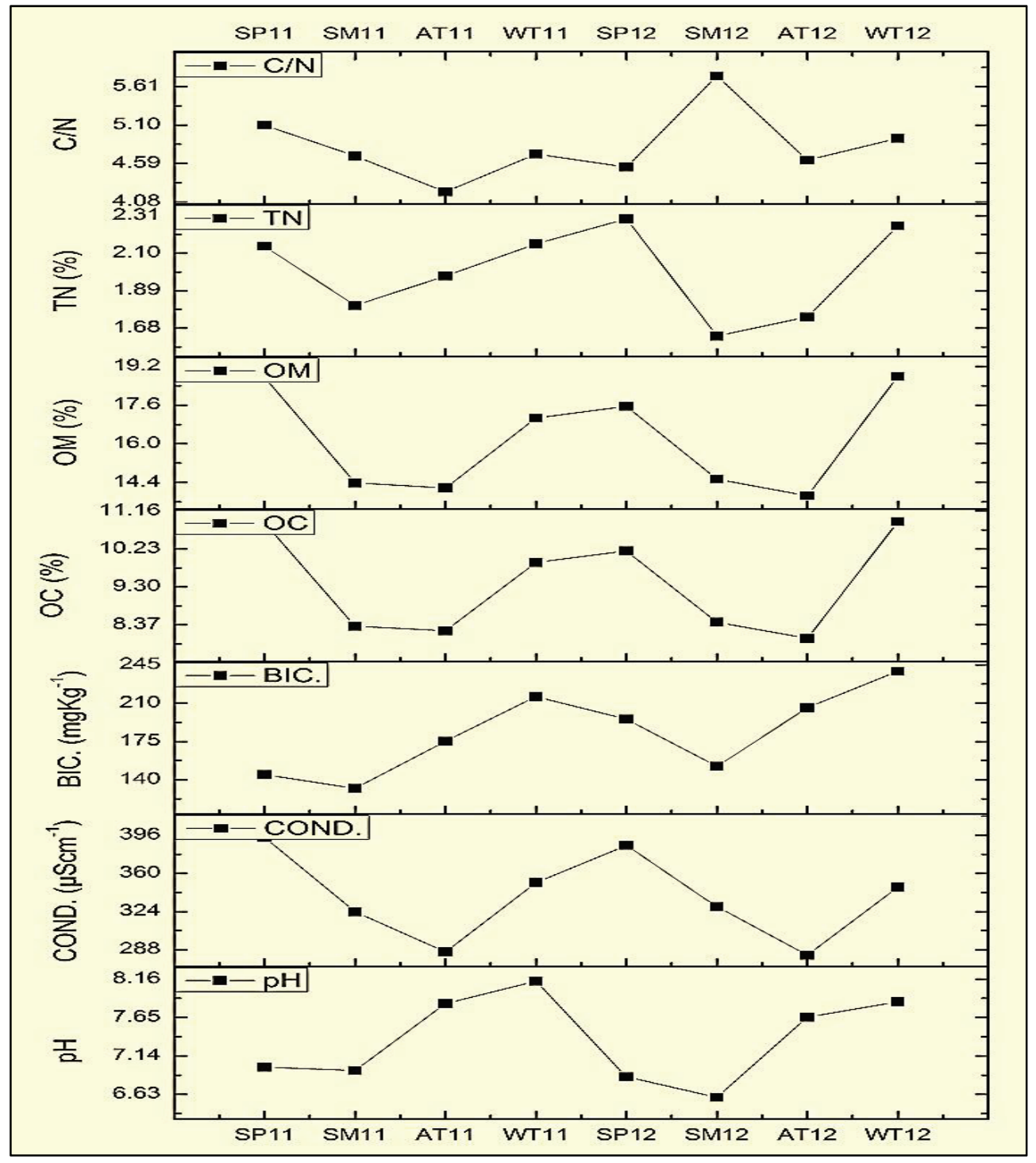

Figure 10. Seasonal fluxes in sediments [SP, SM, AT and WT correspond to 4 seasons of years 2011 \& 2012].

(b) Surface Sediments: Sediment report presenting seasonal quantification marks a distinctive outcome. The detected range of $\mathrm{H}$-ion concentration in surface sediments is 6.1 to 8.3 and the respective mean site values include $7.58 \pm 0.42,7.20 \pm 0.58$ and $7.49 \pm 0.56$. Sediment conductivity fluctuated between 234 and $498 \mathrm{\mu Scm}^{-1}$ at $25{ }^{\circ} \mathrm{C}$ and the average inter-site contrast is as $293.3 \pm 36.4,363.3 \pm 50.9$ and $323.3 \pm 38.4$ $\mu \mathrm{Scm}^{-1}$ respectively. The sediment bicarbonate content has minima of 116 and maxima of $264 \mathrm{mgKg}^{-1}$ and varied between the designated sites as $169.8 \pm 41.5,172.6 \pm 41.9$ and $189.6 \pm 42.3 \mathrm{mgKg}^{-1}$ congruently. The ranges and average site wise percentage dry-weight variations in sediment organic carbon (OC), 
organic matter $(\mathrm{OM})$, total nitrogen $(\mathrm{TN})$ and $\mathrm{C} / \mathrm{N}$ ratio are abridged in Table 5. Similarly, the percentage (\%) seasonal sediment composition on dry weight (DW) basis of $\mathrm{Ca}, \mathrm{Cl}, \mathrm{K}, \mathrm{Mg}, \mathrm{Na}, \mathrm{P}, \mathrm{S}$ and Si along with their averages, standard deviations and ranges at the specified sites are given in Table 6 . Pearson correlation matrix of select sediment parameters establish significant relationship between $\mathrm{pH}$ and bicarbonates $(\mathrm{p}<0.05)$, conductivity and OC or else OM ( $\mathrm{p}<0.01)$, OC and OM or also TN (p $<0.01)$, and $\mathrm{OM}$ and TN $(\mathrm{p}<0.01)$. A temporal trend of the aforementioned sediment characteristics for contiguous eight seasons of two year study can be visualised in Fig. 10. The assessed average percentage elemental composition of surface sediment on DW basis (Fig. 11) presented a minor inter-seasonal difference and follow the dominance order of $\mathrm{Si}>\mathrm{Ca}>\mathrm{Mg}>\mathrm{K}>\mathrm{Na}>\mathrm{P}>\mathrm{S}>\mathrm{Cl}$. Besides, the average micro- and trace- element quantification (Fig. 12) persisted seasonally almost uniform and denote the descending series of $\mathrm{Fe}>\mathrm{Al}>\mathrm{Zn}>\mathrm{Mn}>\mathrm{Cu}>\mathrm{Cr}>\mathrm{Ni}>\mathrm{Co}>\mathrm{As}>\mathrm{Sn}>\mathrm{Pb}>\mathrm{Cd}$ while $\mathrm{Hg}$ and Se as BDL. The calculation of Enrichment Factor (EF) in Table 7 organises each trace element into 'No Enrichment' to 'Very High Enrichment' classes in accordance to [31] interpretation. The measures of Geochemical Index $\left(\mathrm{I}_{\text {geo }}\right)$ scale in Table 7 labels 'Unpolluted' to 'Highly Polluted' element sets in sediments [32]. Integrated Pollution Index (IPI) score of 3.22 corresponds to 'High Level of Pollution' and Pollution Load Index (PLI) tally of 1.21 categorizes the lake as 'Unpolluted to Moderately Polluted' on the scales of [33] and [34] respectively. The construal of Contamination Factor (CF) differentiates between 'Contaminated' and 'Uncontaminated' score of elements in Table 7 as per [35]. The various Sediment Quality Guidelines' (SQG) like Threshold Effect Level (TEL), Effects Range Low (ERL), Lowest Effect Level (LEL), Probable Effect Concentrations (PEC) and Threshold Effect Concentrations (TEC) are matched to the identified mean values for various elements in Table 8 inorder to establish their pollution status and concomitant ecological risks [36] and [37].

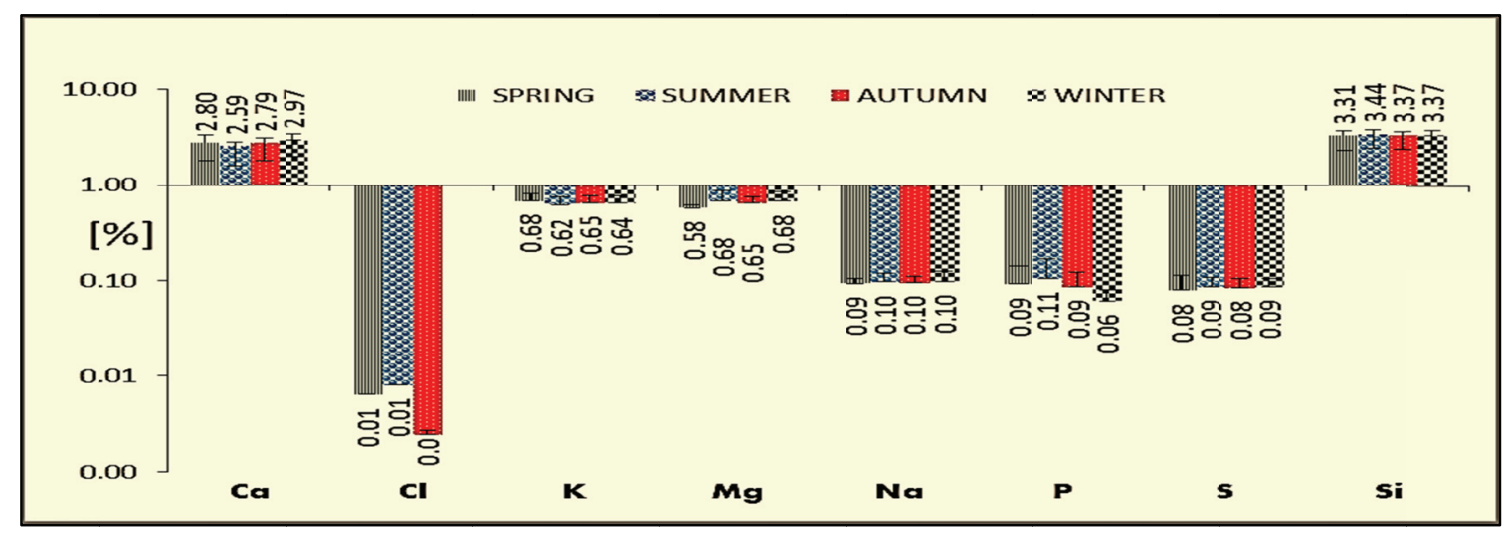

Figure 11. Average percentage elemental composition of surface sediments.

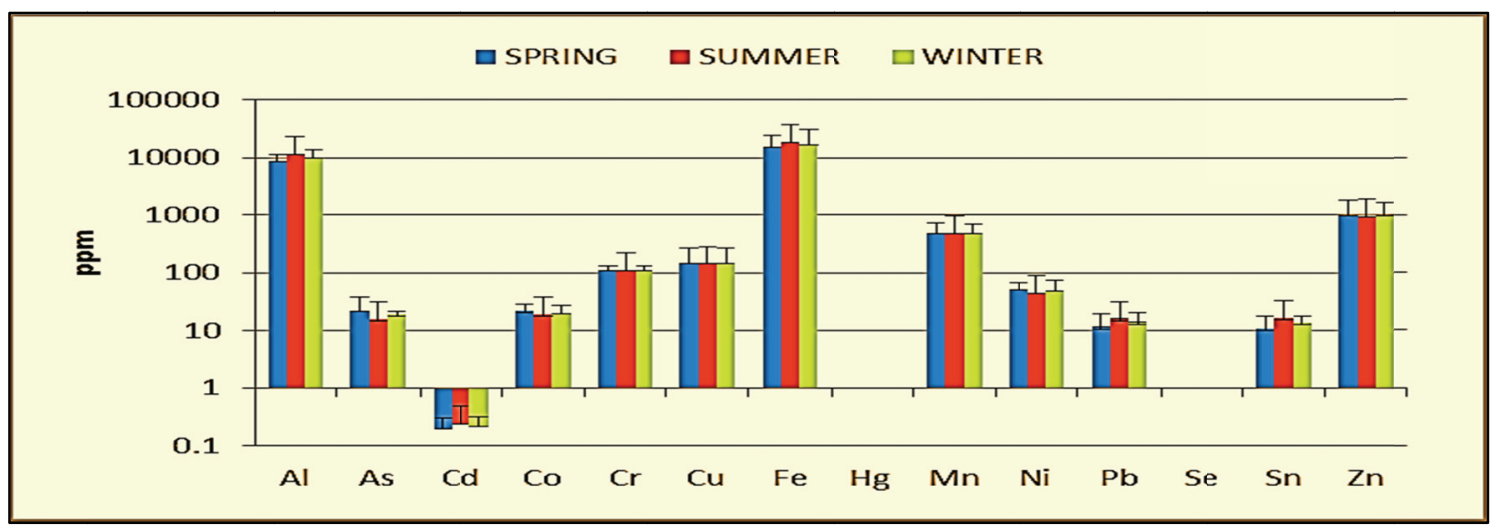

Figure 12. Mean micro- and trace- element quantification. 
Table 5. Organic carbon (OC), organic matter (OM), total nitrogen $(\mathrm{TN})$ and $\mathrm{C} / \mathrm{N}$ ratio in sediments.

\begin{tabular}{ccccc}
\hline SEDIMENT-VARIABLE & RANGE & D1 & D2 & D3 \\
\hline OC (\%) & 6.7 to 15.21 & $8.67 \pm 0.84$ & $9.83 \pm 1.27$ & $7.85 \pm 0.77$ \\
OM (\%) & 11.55 to 26.22 & $14.940 \pm 1.442$ & $16.939 \pm 2.178$ & $13.526 \pm 1.327$ \\
TN (\%) & 1.09 to 2.87 & $1.864 \pm 0.306$ & $1.900 \pm 0.174$ & $2.458 \pm 0.322$ \\
C/N RATIO & 2.55 to 7.53 & $4.789 \pm 0.948$ & $5.175 \pm 0.554$ & $3.229 \pm 0.373$ \\
\hline
\end{tabular}

Table 6. Elemental composition (\%) of surface sediments on dry weight basis.

\begin{tabular}{|c|c|c|c|c|c|c|c|}
\hline ELEMENT & SEASON & D1 & $\mathrm{D} 2$ & D3 & AVERAGE & MINIMUM & MAXIMUM \\
\hline & SPRING & 3.67 & 3.32 & 2.11 & $2.798 \pm 0.596$ & 2.11 & 3.67 \\
\hline & SUMMER & 2.76 & 2.50 & 2.91 & $2.592 \pm 0.208$ & 2.36 & 2.91 \\
\hline $\mathrm{Ca}$ & AUTUMN & 3.11 & 3.13 & 2.74 & $2.788 \pm 0.305$ & 2.31 & 3.13 \\
\hline & WINTER & 2.89 & 3.56 & 3.20 & $2.973 \pm 0.444$ & 2.21 & 3.56 \\
\hline & AVERAGE & $3.107 \pm 0.349$ & $3.127 \pm 0.394$ & $2.739 \pm 0.400$ & \multicolumn{3}{|c|}{ Range $=2.11$ to 3.67} \\
\hline \multirow{5}{*}{$\mathrm{Cl}$} & SPRING & BDL & BDL & BDL & 0.006 & 0.006 & 0.006 \\
\hline & SUMMER & BDL & BDL & BDL & 0.008 & 0.008 & 0.008 \\
\hline & AUTUMN & BDL & BDL & BDL & 0.002 & 0.002 & 0.003 \\
\hline & WINTER & BDL & BDL & BDL & BDL & BDL & BDL \\
\hline & AVERAGE & $\mathrm{BDL}$ & BDL & BDL & \multicolumn{3}{|c|}{ Range $=0.002$ to 0.008} \\
\hline \multirow{5}{*}{$\mathrm{K}$} & SPRING & 0.70 & 0.92 & 0.66 & $0.682 \pm 0.133$ & 0.56 & 0.92 \\
\hline & SUMMER & 0.62 & 0.87 & 0.54 & $0.623 \pm 0.129$ & 0.53 & 0.87 \\
\hline & AUTUMN & 0.71 & 0.85 & 0.56 & $0.649 \pm 0.118$ & 0.53 & 0.85 \\
\hline & WINTER & 0.81 & 0.76 & 0.48 & $0.643 \pm 0.135$ & 0.48 & 0.81 \\
\hline & AVERAGE & $0.711 \pm 0.067$ & $0.851 \pm 0.061$ & $0.561 \pm 0.067$ & \multicolumn{3}{|c|}{ Range $=0.48$ to 0.92} \\
\hline \multirow{5}{*}{$\mathrm{Mg}$} & SPRING & 0.61 & 0.59 & 0.53 & $0.577 \pm 0.040$ & 0.53 & 0.62 \\
\hline & SUMMER & 0.47 & 0.52 & 0.63 & $0.685 \pm 0.186$ & 0.47 & 0.91 \\
\hline & AUTUMN & 0.55 & 0.53 & 0.58 & $0.646 \pm 0.115$ & 0.53 & 0.80 \\
\hline & WINTER & 0.57 & 0.47 & 0.60 & $0.677 \pm 0.165$ & 0.47 & 0.88 \\
\hline & AVERAGE & $0.549 \pm 0.053$ & $0.529 \pm 0.043$ & $0.584 \pm 0.036$ & \multicolumn{3}{|c|}{ Range $=0.47$ to 0.91} \\
\hline \multirow{5}{*}{$\mathrm{Na}$} & SPRING & 0.11 & 0.09 & 0.08 & $0.094 \pm 0.011$ & 0.08 & 0.11 \\
\hline & SUMMER & 0.13 & 0.10 & 0.06 & $0.096 \pm 0.023$ & 0.06 & 0.13 \\
\hline & AUTUMN & 0.11 & 0.09 & 0.07 & $0.096 \pm 0.015$ & 0.07 & 0.11 \\
\hline & WINTER & 0.09 & 0.09 & 0.08 & $0.097 \pm 0.027$ & 0.08 & 0.15 \\
\hline & AVERAGE & $0.111 \pm 0.015$ & $0.092 \pm 0.003$ & $0.072 \pm 0.007$ & \multicolumn{3}{|c|}{ Range $=0.06$ to 0.15} \\
\hline \multirow{5}{*}{$\mathrm{P}$} & SPRING & 0.09 & 0.18 & 0.07 & $0.092 \pm 0.050$ & 0.03 & 0.18 \\
\hline & SUMMER & 0.09 & 0.23 & 0.08 & $0.105 \pm 0.064$ & 0.05 & 0.23 \\
\hline & AUTUMN & 0.08 & 0.15 & 0.08 & $0.086 \pm 0.034$ & 0.04 & 0.15 \\
\hline & WINTER & 0.06 & 0.03 & 0.09 & $0.061 \pm 0.018$ & 0.03 & 0.09 \\
\hline & AVERAGE & $0.082 \pm 0.011$ & $0.148 \pm 0.072$ & $0.078 \pm 0.007$ & \multicolumn{3}{|c|}{ Range $=0.03$ to 0.23} \\
\hline \multirow{5}{*}{$\mathrm{S}$} & SPRING & 0.04 & 0.07 & 0.08 & $0.079 \pm 0.034$ & 0.04 & 0.14 \\
\hline & SUMMER & 0.08 & 0.06 & 0.08 & $0.086 \pm 0.022$ & 0.06 & 0.13 \\
\hline & AUTUMN & 0.07 & 0.06 & 0.09 & $0.084 \pm 0.022$ & 0.06 & 0.13 \\
\hline & WINTER & 0.10 & 0.06 & 0.10 & $0.086 \pm 0.020$ & 0.06 & 0.11 \\
\hline & AVERAGE & $0.069 \pm 0.021$ & $0.063 \pm 0.005$ & $0.087 \pm 0.007$ & \multicolumn{3}{|c|}{ Range $=0.04$ to 0.14} \\
\hline \multirow{5}{*}{$\mathrm{Si}$} & SPRING & 2.79 & 3.17 & 3.13 & $3.313 \pm 0.375$ & 2.79 & 3.77 \\
\hline & SUMMER & 3.34 & 2.90 & 3.24 & $3.439 \pm 0.375$ & 2.90 & 3.91 \\
\hline & AUTUMN & 3.23 & 3.17 & 3.12 & $3.373 \pm 0.271$ & 3.12 & 3.84 \\
\hline & WINTER & 3.56 & 3.44 & 2.99 & $3.367 \pm 0.333$ & 2.99 & 3.85 \\
\hline & AVERAGE & $3.230 \pm 0.281$ & $3.167 \pm 0.192$ & $3.119 \pm 0.089$ & \multicolumn{3}{|c|}{ Range $=2.79$ to 3.91} \\
\hline
\end{tabular}


Table 7. Elemental enrichment factor $(\mathrm{EF})$, geochemical index ( $\left.\mathrm{I}_{\text {geo }}\right)$ and contamination factor $(\mathrm{CF})$.

\begin{tabular}{cccc}
\hline Element & EF & Igeo & CF \\
\hline $\mathrm{Al}$ & no enrichment $(<1)$ & unpolluted $(\leqslant 0)$ & uncontaminated $<1$ \\
$\mathrm{As}$ & very high $(20-40)$ & moderately to highly polluted $(\leqslant 3)$ & contaminated $>1$ \\
$\mathrm{Cd}$ & moderate $(2-5)$ & unpolluted to moderately polluted $(\leqslant 1)$ & contaminated $>1$ \\
$\mathrm{Co}$ & moderate $(2-5)$ & unpolluted $(\leqslant 0)$ & contaminated $>1$ \\
$\mathrm{Cr}$ & moderate $(2-5)$ & unpolluted $(\leqslant 0)$ & contaminated $>1$ \\
$\mathrm{Cu}$ & significant $(5-20)$ & moderately polluted $(\leqslant 2)$ & contaminated $>1$ \\
$\mathrm{Fe}$ & minor $(<3)$ & unpolluted $(\leqslant 0)$ & uncontaminated $<1$ \\
$\mathrm{Mn}$ & minor $(<3)$ & unpolluted $(\leqslant 0)$ & uncontaminated $<1$ \\
$\mathrm{Ni}$ & minor $(<3)$ & unpolluted $(\leqslant 0)$ & uncontaminated $<1$ \\
$\mathrm{~Pb}$ & minor $(<3)$ & unpolluted $(\leqslant 0)$ & uncontaminated $<1$ \\
$\mathrm{Sn}$ & moderate $(2-5)$ & unpolluted to moderately polluted $(\leqslant 1)$ & contaminated $>1$ \\
$\mathrm{Zn}$ & very high $(20-40)$ & highly polluted $(\leqslant 4)$ & contaminated $>1$ \\
\hline
\end{tabular}

Table 8. A comparative of sediment quality guidelines [TEL; ERL; LEL; PEC and TEC] with observed mean element concentrations.

\begin{tabular}{|c|c|c|c|c|c|c|}
\hline \multicolumn{7}{|c|}{ Sediment Quality Guidelines $\left[\mathrm{mgKg}^{-1}\right.$ or ppm or $\left.\mathrm{\mu gg}^{-1}\right]$} \\
\hline ELEMENT & TEL & ERL & LEL & PEC & TEC & OBSERVED MEAN \\
\hline As & 5.9 & 33 & 6 & * & $*$ & 17.1 \\
\hline $\mathrm{Cd}$ & 0.6 & 5 & 0.6 & 5 & 1 & 0.2 \\
\hline $\mathrm{Cr}$ & 37.3 & 80 & 26 & 110 & 43 & 114.1 \\
\hline $\mathrm{Cu}$ & 35.7 & 70 & 16 & 150 & 32 & 141.5 \\
\hline $\mathrm{Pb}$ & 35 & 35 & 31 & 130 & 36 & 13.3 \\
\hline $\mathrm{Hg}$ & 0.17 & 0.15 & 0.2 & $*$ & $*$ & $*$ \\
\hline $\mathrm{Ni}$ & 18 & 30 & 16 & 49 & 23 & 50.0 \\
\hline $\mathrm{Zn}$ & 123 & 120 & 120 & 460 & 120 & 975.2 \\
\hline
\end{tabular}

(*indicates unknown value)

(c) Macrophyte analysis: The biochemical assays of select macrophytes for appropriate parameters carried out in tandem with water and sediment associates unveil their organised and inter-reliant interacting. The highest total chlorophyll concentration is noted in Ceratophyllum demersum $\left(0.92 \mathrm{mgg}^{-1}\right)$ during its peak growth at site D3 while a minimum $0.02 \mathrm{mgg}^{-1}$ is recorded both in case of Myriophyllum $\underline{\text { aquaticum }}$ at site D2 and Salvinia natans at site D3 throughout senescence. The individual ranges of chlorophyll content $\left(\mathrm{mgg}^{-1}\right)$ for $\underline{M}$. aquaticum, $\underline{N}$. nucifera, $\underline{C}$. demersum and $\underline{S}$. $\underline{\text { natans }}$ include 0.02 to $0.37,0.05$ to $0.72,0.10$ to 0.92 and 0.02 to 0.87 respectively. The productive capability of the explored macrophytes calculated on the basis of dry weight mean biomass $\left(\mathrm{gm}^{-2}\right)$ for each experimental species in the three major growth phases is presented in Fig. 13. The biomass calculations reflect subsequent ranges for each species: $\underline{M}$. aquaticum $\left(107\right.$ to $\left.960 \mathrm{gm}^{-2}\right), \underline{N}$. $\underline{\text { nucifera }}$ (66 to $\left.750 \mathrm{gm}^{-2}\right)$, $\underline{\text { C. }}$ demersum (39 to $231 \mathrm{gm}^{-2}$ ) and $\underline{S}$. natans $\left(01\right.$ to $55 \mathrm{gm}^{-2}$ ). In terms of mean peak dry weight biomass values $M$. $\underline{\text { aquaticum }}\left(880.2 \mathrm{gm}^{-2}\right)$ dominated $\underline{N}$. nucifera $\left(678.4 \mathrm{gm}^{-2}\right), \underline{C} . \underline{\text { demersum }}\left(182.4 \mathrm{gm}^{-2}\right)$ and $S . \underline{\text { natans }}$ (45 $\left.\mathrm{gm}^{-2}\right)$. A similar fashion low occurred in dry weight $\left(\mathrm{gm}^{-2}\right)$ during their senescence period ranking by way of $152.4>75.4>49>4.2$ respectively. The percentage contribution of various life form classes among the studied macrophytes towards production (dry weight biomass, $g m^{-2}$ ) as well as specific per cent relative difference during sprouting, peak growth and senescence phases is described in pie-chart illustrations accessible in Fig. 14. Other biomass parameters like Productivity $\left(\mathrm{g} \mathrm{m}^{-2}\right.$ day $\left.^{-1}\right)$, Net Primary Productivity (NPP, gm ${ }^{-2}$ ) and Specific Growth Rate $\left(\right.$ day $\left.^{-1}\right)$ establish uniform variations in the experimental species of the order: emergent $\underline{M}$. aquaticum $>$ rooted floating $\underline{N}$. $\underline{\text { nucifera }}>$ submerged $\underline{C}$. $\underline{\text { demersum }}>$ free floating $\underline{S}$. $\underline{\text { natans }}$ but Species Turnover is highest in case of $\underline{S}$. $\underline{\text { natans }}$ and lowest for C. demersum. 


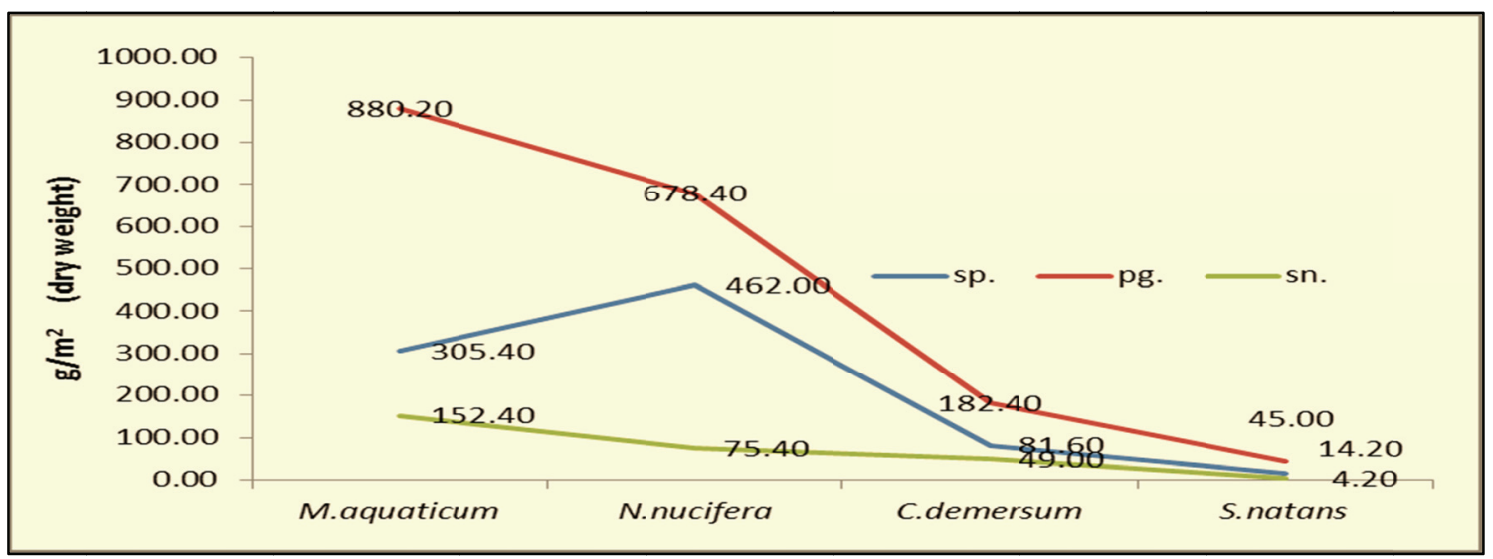

Figure 13. Average biomass values $\left(\mathrm{gm}^{-2}\right.$ dry weight).

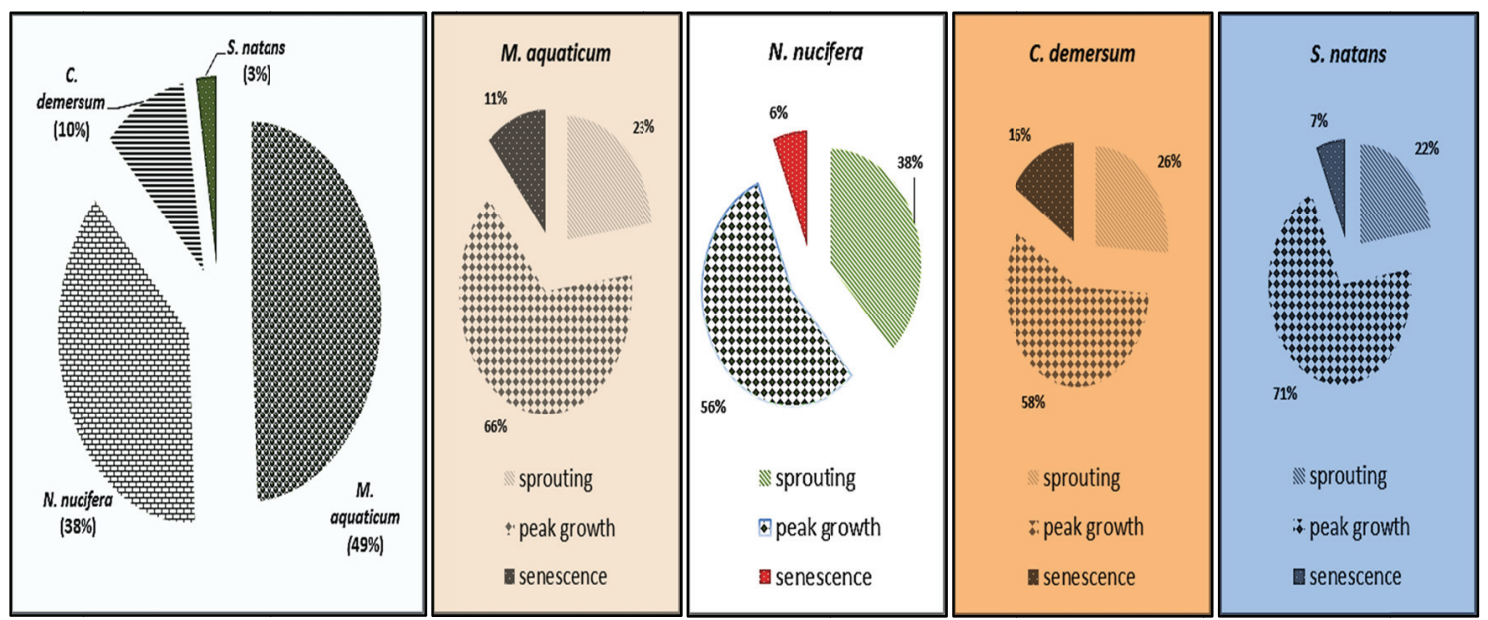

Figure 14. A comparative of percent dry weight biomass $\left(\mathrm{gm}^{-2}\right)$ across growth-phases and species.

The average tissue concentration of analysed elements fluctuated not only between the select species but also depicted growth-phase variations within the same species. However, no significant site contrasts were noticed. The ANOVA test conducted between the species for the mineral composition of macrophytes convey significance for $\mathrm{Cu}(\mathrm{p}<0.05)$, K $(\mathrm{p}<0.001)$, Na $(\mathrm{p}<0.05)$, Se $(\mathrm{p}<0.01)$ and $\mathrm{Si}$ $(\mathrm{p}<0.01)$ only. Whereas ANOVA for their growth-phases reflect significance in case of $\mathrm{Al}(\mathrm{p}<0.05)$, As $(\mathrm{p}<0.001)$, Ca $(\mathrm{p}<0.05)$, Co $(\mathrm{p}<0.05)$, Cr $(\mathrm{p}<0.05)$, Fe $(\mathrm{p}<0.05), \mathrm{Mg}(\mathrm{p}<0.05)$, Mn $(\mathrm{p}<$ $0.001), \mathrm{Ni}(\mathrm{p}<0.01), \mathrm{Pb}(\mathrm{p}<0.01)$ and $\mathrm{Zn}(\mathrm{p}<0.001)$. The Bioconcentration Factor $(\mathrm{BCF})$ criterion adopted indicates hyperaccumulation phenomenon for most of the micro- and trace- elements in $\underline{C}$. $\underline{\text { demersum }}$ and $\underline{S}$. natans except for $\mathrm{Pb}, \mathrm{Sn}$ and $\mathrm{Zn}$. And $\underline{M}$. aquaticum hyperaccumulates $\mathrm{Cd}$ and $\mathrm{Mn}$ while $\underline{N}$. nucifera Mn only. The Removal Potential of the macrophytes clearly stipulates species specific variation ensuing a generalized arrangement of emergent $\underline{M}$. aquaticum $>$ rooted floating $\underline{N}$. $\underline{\text { nucifera }}>$ submerged $\underline{C} . \underline{\text { demersum }}>$ free floating $\underline{S} . \underline{\text { natans. }}$.

\section{Discussion}

The deliberation is compliant to inter-annual insitu compartmentalization and phytofiltration of major, minor and trace elements within the principal structural integrals of the lacustrine ecosystem. At the inception general condition of the bulk lake-ecosystem component of water on a spatio-temporal basis pronounce its hydro-geomorphological setting. Next, the sediment characterisation and comparison provides an insight into its influences on the system. Later, the biotic features of macrophytes are 
considered in terms of their function and interrelationships with other compartments. Water quality [38], sediment characteristics [39], biological indicators [40] and even key ecological processes like primary production [41] are crucial to assess the integrity and health of the ecosystem. The temporal variation in ionic composition of natural waters along with its spatial distribution in a region aids significantly to distinguish the source [42].

The limnochemical statistics that developed during the study retro expound unambiguous and unavoidable evolving physico-biochemical configuration of the lake under multiple anthropogenic stress [43]. The chemical composition of water closely related to dual factors of connected catchment and human intervention thereof [44]. The trophic range oscillated within the eutrophic limits. But for the semi-drainage type hydrology flushing via fixed drainage channels and improved by ephemeral and subaqueous inputs vitalized the self-reclaimed homeostasis by way of keeping together the basin holdingtime of water low $\left(2^{1 / 2}\right.$ months). The statistical insignificance in recorded epilimnion temperature variance as well as significant temporal inconsistency discloses similar geo-climatic setting of the lakes. Even if the entire recorded $\mathrm{pH}$ profile $(>7)$ reflects buffered waters but has prominent variance both site- and time-wise suggesting position and period specific photosynthetic activity that removes $\mathrm{HCO}_{3}^{-}$ thereby enriching diurnal $\mathrm{pH}$ [45]. Contrarily, poorer $\mathrm{pH}$ during winter apparently on account of excess carbonic acid generation is due to higher [Respiration : Photosynthesis] proportion. The ionic strength (conductivity) measures vindicate superior eutrophy (solute richness) besides autotrophic assimilation and biocalcification contributing towards its summer falls [46]. Cationic progression is as $\mathrm{Ca}>\mathrm{Mg}>$ $\mathrm{Na}>\mathrm{K}$ [5], along with anionic predominance of $\mathrm{HCO}_{3}^{-}$and $\mathrm{Cl}^{-}$[47]. The lime grade catchment characteristic [48] contributed to Ca dominance phenomenon and hard water type classification [49]. K features base association with agricultural runoff and $\mathrm{Cl}$ to faunal organic pollution [50]. Although a range of human actions (agriculture, farming, sewage, factories, etc.) result in $\mathrm{N}$ species inflow [51], the spring fed basin of the lake and preferential reduced $\mathrm{NH}_{4}{ }^{+}$autotrophic assimilation instead of oxidised $\mathrm{NO}_{3}{ }^{-}$also better concentration of nitrate $-\mathrm{N}$ in water [1]. Additionally, [48] ascribed isolated geogenic $\mathrm{N}$ pockets as evaporative deposits in phyllite, schist and carbonate bed rocks in Kashmir. Forest surface runoff also contain $\leqslant 20 \mathrm{mgL}^{-1}$ nitrate as a natural source to lakes [52]. Summer decreases of the least abundant macronutrient $(\mathrm{P})$ limits bio-productivity owing to its utilization and carbonate coprecipitation [53]. The overall total $\mathrm{P}$ limit surpassed critical eutrophic index $\left(\leqslant 0.05 \mathrm{mgL}^{-1}\right) \mathrm{but}^{-1}$ nitrate $\mathrm{N}$ persisted underneath it $\left(\leqslant 0.5 \mathrm{mgL}^{-1}\right)$ mostly [54].

The correlation matrix verily suggests temperature increments elevating $\mathrm{pH}$ but diminishing conductivity, $\mathrm{HCO}_{3}^{-}, \mathrm{Ca}, \mathrm{Mg}, \mathrm{Na}, \mathrm{K}$ and $\mathrm{P}$ significantly [55]. However, $\mathrm{Cl}$ and $\mathrm{NO}_{3}-\mathrm{N}$ remain unaffected due to temperature and $\mathrm{pH}$ ordeal. The influence of $\mathrm{pH}$ improvements correlate negatively with conductivity as well. Subsequently, the factors of temperature and $\mathrm{pH}$ clearly state that improved growth environment for biological uptake and calcite co-precipitation of ions reduce their epilimnion concentrations in peak growth summer cycle. Such a systematics attributed to photosynthetically induced precipitation and utilization by autotrophs is concomitant to the studies of [56]. The only negative association of $\mathrm{NO}_{3}-\mathrm{N}$ with $\mathrm{HCO}_{3}^{-}$shows eutrophication navigates on $\mathrm{C}$ assimilation for it serves as the main inorganic $\mathrm{N}$ source [57]. The close covariance of $\mathrm{P}$ with $\mathrm{Ca}, \mathrm{Mg}, \mathrm{Na}$ and $\mathrm{K}$ depict their analogous limited absorbance constraint by the biota. A supportive understanding of water variable interaction offers significant coefficient of determination $\left(\mathrm{R}^{2}\right)$ alongside simple least square regression lines [58] for $\mathrm{pH}$ versus temperature (0.8), conductivity versus $\mathrm{pH}(0.9)$, conductivity versus temperature (0.8) and BIC versus temperature (0.5). An equation with the world average stream content $\left(\mathrm{mgL}^{-1}\right)$ of recorded $\mathrm{Ca}(>15), \mathrm{Mg}(>4), \mathrm{K}(>2.3)$ and $\mathrm{Na}(>6.3)$ acclaim noticeable human inputs from common uses like fertilizers, plaster, pigments, lime, alloys, pharmaceuticals, batteries, food additives, glass, baking powder, soft drinks, electroplating, caustic soda, water treatment chemicals, etc. [17]. ANOVA discloses significant seasonal variance in temperature, $\mathrm{pH}$, conductivity and BIC compared to significant site contrasts for $\mathrm{Cl}, \mathrm{Mg}, \mathrm{Na}, \mathrm{K}, \mathrm{NO}_{3}-\mathrm{N}$ and $\mathrm{P}$ [59] and [60]. The BIC, $\mathrm{Cl}, \mathrm{Ca}, \mathrm{Mg}, \mathrm{Na}$, $\mathrm{K}$, nitrate $\mathrm{N}$ and total $\mathrm{P}$ display virtually a matching situation of withdrawal throughout highest growth periods of macrophytes and once more pickup in post senescence period [2] and [61]. Anthropogenic effluents are recognized prime sources of traces in surface waters [62]. While paralleling the observed average epilimnion trace element concentration $\left(\mathrm{\mu LL}^{-1}\right)$ with the average global stream abundance [17] in absence of any baseline data, an intense skewed ascent for $\mathrm{As}(\sim 10>2)$, $\mathrm{Cd}(\sim 3>1)$, $\mathrm{Cr}(\sim 40>1)$, $\mathrm{Co}(\sim 10>0.2), \mathrm{Cu}(\sim 130>10), \mathrm{Fe}(\sim 5600>700), \mathrm{Pb}(\sim 90>3), \mathrm{Mn}(\sim 600>7), \mathrm{Ni}(\sim 30>1), \mathrm{Se}$ $(\sim 9>0.2)$, Sn $(\sim 190>0.1)$ and $\mathrm{Zn}(\sim 18520>20)$ proclaim their anthropogenic origins [63]. 
Pertinently, such proportions exceed maximum permissible limits for drinking water but are suitable as irrigation liquid ordinarily [9] and [64]. The exceptions of $\mathrm{Fe}\left(>5 \mathrm{mgL}^{-1}\right)$ and $\mathrm{Zn}\left(>2 \mathrm{mgL}^{-1}\right)$ enhance the maximal concentrations in irrigation recommendations [65]. Still, Zn has lesser toxicity in organic soils at $\mathrm{pH}>6$ and $\mathrm{Fe}$ contributes towards acidification and reduced $\mathrm{P}$ availability. Al, a non-priority pollutant at $\mathrm{pH} 6.5$ to 9 is well below the freshwater Criterion Continuous Concentration (CCC) chronic exposure limit of $\geqslant 87 \mathrm{\mu gL}^{-1}$. Fe exceeds CCC at $>1000 \mathrm{\mu gL}^{-1}$ too. But all the priority pollutants of As, $\mathrm{Cd}, \mathrm{Cr}, \mathrm{Cu}, \mathrm{Pb}, \mathrm{Ni}$ and Se remained below chronic level of CCC except Zn [9]. The complexing phenomena of heavy metals with carbonate and BIC limit their direct or indirect outcomes [66].

PCA biplot reveal the water variables contributed $89 \%$ with the most important being conductivity, $\mathrm{K}, \mathrm{Na}, \mathrm{Mg}, \mathrm{Ca}, \mathrm{P}, \mathrm{HCO}_{3}, \mathrm{NO}_{3}-\mathrm{N}$ and $\mathrm{Cl}$ for the first axis $(60.27 \%)$ whereas in the second axis $(28.73 \%)$ temperature and $\mathrm{pH}$ predominated. Both temperature and $\mathrm{pH}$ show inverse relationship whereas conductivity is strongly associated with rest of the ions [67]. Again temperature and $\mathrm{pH}$ increments compared to all ions imply their decrements due to absorption. Conductivity subtends an obtuse angle (cosines of the angles) ( $\cos \theta$ ) with respect to temperature and $\mathrm{pH}$, so, the projection showcases a high negative correlation. But a high positive correlation appears for conductivity and other ions due to acute $\cos \theta$ represented in the biplot in approximately same orientation. BIC, conductivity, nitrate $-\mathrm{N}$ and $\mathrm{TP}$ as the more important variables (high contributors) to interpret corresponding to their higher regression coefficients due to longer vectors closer to the unit circle [68].

The abiotic quiescent zone of sediments is suitable long-term indicator of lake environmental conditions [69] and [70]. Sediment nutrient constitution corresponds to catchment land use [71]. They provide settling space for water carried elements, both acquired and innate, in the form of ions, organic/inorganic- complexes and dissolved/suspended- matter associations [72]. Sediments reflect weaker source but stronger sink behaviour and capacity depicted via transformations of adsorption/desorption, mineralization/demineralization, bioassimilation and burial phenomenon [73]. Alkaline $\mathrm{pH}$ records of the sediment in general determine the catchment calcite predominance [48] whereas slight summer diminution is temperature improved OM decomposition effect. [74] labelled sediment $\mathrm{pH}$ as the principal factor enacting nutrient accessibility and movement. The seasonal organic - C changes in sediments aptly describe a pattern of temperature induced decrement during summers fulfilling the mineralization promotion [75]. The analysis of superficial sediment chemical characters reveals connections with trophic index [76]. Besides, eutrophication is evidenced to influence $\mathrm{C}$ flow in lakes to the effect of $0.6 \mathrm{PgY}^{-1}$ global $\mathrm{OC}$ burial [77] and [78]. The typical $<10 \mathrm{C} / \mathrm{N}$ implies autochthonous $\mathrm{OM}[2]$, besides low decomposition rates controlled by $\mathrm{N}$ budgeting and speciation via biochemical (enzyme and $\mathrm{pH}$ ) fluctuations under alkaline conditions [79]. Its possible reason could be $\mathrm{NH}_{4}{ }^{+}$microbial preference instead of $\mathrm{NO}_{3}{ }^{-}$stimulating decomposition despite eutrophied state [80]. $\mathrm{NO}_{3}{ }^{-}$ exacerbations also shift decomposer community structure from fungal to bacterial causing $\mathrm{OM}$ decomposition decline [81]. Hence, eutrophied shallow lakes favour C sequestration. Surface sediments harbouring maximum OM profoundly determine biogeochemical cycling of major, minor and trace elements [2]. Significant correlation occurred for conductivity with $\mathrm{OC}$ and $\mathrm{OM}$ as the latter serves an established source for nutrient ions. Similar is the case with sediment OC, OM and TN as being complementary to one another.

Improved N:P ratios parallel chronic nitrogen influx in P-limited lakes [82], however, N-limited lakes suffer greater eutrophication catastrophes [83]. Higher temperature and lower N:P ratio during summer develop the $\mathrm{P}$ internal loading process. This $\mathrm{P}$ recycling mediates via degradation (oxic), denitrification and sulphate reduction [84]. Nonetheless, higher $\mathrm{Al}, \mathrm{Ca}$ and $\mathrm{Fe}$ proportions in sediments inactivate $\mathrm{P}$ mobilization [85]. Curbing the external $\mathrm{N}$ and $\mathrm{P}$ loads is effective in remediation but the sediment internal loading supplement compensates the loss [86]. Meanwhile sediment dredging is beneficial for internal nutrient deloading only after the external inputs are checked [87]. Trace metals bound to OM or $\mathrm{Fe} / \mathrm{Mn}$ - oxides separate on their decomposition [88] and reductive dissolution respectively near hypolimnion-sediment overlap [85]. A comparative of sediment-water compartmentalization for different elements exhibit more retention potential for the sediment component conform their sink-selves. Assuming the immensity and multifaceted networking in insitu conditions only a slight inconsistent inter-seasonal variance of $\mathrm{Ca}, \mathrm{Cl}, \mathrm{K}, \mathrm{Mg}, \mathrm{Na}, \mathrm{P}$ and $\mathrm{Si}$ were observed. But $\mathrm{BIC}$, conductivity, $\mathrm{pH}, \mathrm{OM}$, $\mathrm{TN}$ and $\mathrm{C} / \mathrm{N}$ fluxed more on account of additional compartmental exchange quanta. A general gradual decline in nutrient concentration till culmination of active macrophytic growth phase can be associated with active/passive bioaccumulation or anoxic release from sediments [89]. 
Devoid of any universal sediment pollution indicator or guideline, multiple approaches were applied on the recorded holistic seasonal and site contents of micro and trace elements [90]. The EF differentiated very high anthropogenic contamination of As, significant in case of $\mathrm{Cu}$ and none for $\mathrm{Al}$

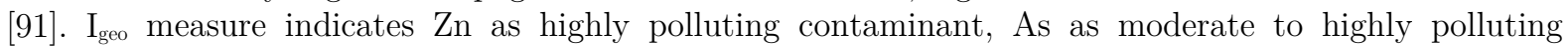
pollutant and $\mathrm{Cu}$ polluting moderately [92]. In the context of IPI and PLI, the selected lake exhibit moderate metal contamination [93]. CF calculations scale contamination with respect to As, $\mathrm{Cd}$, Co, Cr, $\mathrm{Cu}, \mathrm{Sn}$ and $\mathrm{Zn}$ [94]. Furthermore, the observed mean concentration of $\mathrm{Cr}, \mathrm{Ni}$ and $\mathrm{Zn}$ exceed the given sediment quality guidelines posing particular potential ecological risks [95]. However, $\mathrm{Cd}$ and $\mathrm{Pb}$ don't transcend them. Again As is below ERL and Cu lags in PEC [37] and [96]. A generalization of the above indices elucidates the source of contaminants to be chiefly anthropogenic, degrading the sediment profile with hazardous consequences for the dependent biota in the offing [97]. The lower [Ca : Al] values also suggest exsitu human cause for PTE transport to the designated lacustrine sites [73]. Nonetheless, the mobility of PTE's is effectively curtailed by OM enriched sediments and calcite co-precipitation [98].

The selected biomonitors among the macrophyte community manifested both contribution (command) and subservience to its abiotic allies. Macrophytes dominate mineral regulation between sediment and water [99]. They are capable to remove nutrients even at low loading rates [100]. Their adaptive advantage to lock up minerals from nutrient pool is helpful to check degradation primarily and restore mineral loading later on [101]. $\mathrm{N}$ and $\mathrm{P}$ are intimately related to biological productivity of aquatic ecosystems [1]. The productivity also lies in consonance with developmental stage, ambient nutrient medium and physiognomy of a species [102]. Higher temperature favour bio-production and elevate carbonate driven $\mathrm{pH}$ significantly [103]. Among the evaluated species $\underline{\underline{M}}$. aquaticum accumulated $49 \%$ of the dry weight biomass annually, whereas $\underline{S}$. natans contributed only $3 \%$ but it outdid in species turnover comparison. Biomass parameters like dry weight, productivity, NPP and specific growth rate establish similar variations in the experimental species but species turn-over is highest in case of $\underline{S}$. $\underline{\text { natans }}$ and lowest for $\underline{C}$. demersum. Substantial OM productions by macrophytes contribute towards nutrient immobilization and provide OC requirement for denitrification while decaying [104]. The upgraded biomass configuration property establishes an additional nutrient and trace element interception feature of hyperaccumulation from the growth medium [105]. Even if temperate lakes during winter have uniform density nutrient enriched water devoid of thermal stratification, still, productivity is inhibited due to deficient light and temperature levels [106].

The gaining momentum for comprehending phyto-nutrient dynamics and their implications for water quality management or eco-restoration is a subject of site specific (habitat) application of a suitable phytoremediator [107]. The peak nutrient uptake and bioconcentration coincided with peak biomass in summer and autumn. The diminishing conductivity at improved temperature conditions suggest higher bioaccumulation rate of nutrients [108]. The removal potential pattern of the emergent accrued more $\mathrm{Si}$, the rooted floating retained greater $\mathrm{K}$, while the rootless submersed and free floating ones amassed Ca. Although the quantum of removal potential for different elements in the analysed species is divergent but the pattern is related which suggests unselective absorption [109]. The elemental turn-over rates in select macrophytes closer to the reference value of 1 has significance. The vascular aquatic plants possess higher productivity (C:N and C:P ratios) with organic polymer body capacitating their slowed decomposition that improves nutrient and $\mathrm{C}$ capture potential and as a result net autotrophy [110]. The concurrence of peak bioaccumulation and biomass production empowers the concept of high yield harvesting [111]. The harvesting of macrophyte biomass suitably during peak growth phase is perfect to avoid nutrient and metal remobilization from belowground vegetative parts or during senescence leaching on ultimate OM mineralization [112]. Similarly, a mono annual harvesting practice improves height; shoot density and biomass of macrophytes, although leading to nominal increment for mass TN and TP removal rates [113]. The ANOVA comparing the species shows uptake preference mode for $\mathrm{Cu}$, $\mathrm{K}, \mathrm{Na}$, Se and Si indicating specific role in the unlike macrophytes [114]. Contrarily, the growth-phase variance for $\mathrm{Al}, \mathrm{As}, \mathrm{Ca}, \mathrm{Co}, \mathrm{Cr}, \mathrm{Fe}, \mathrm{Mg}, \mathrm{Mn}, \mathrm{Ni}, \mathrm{Pb}$ and $\mathrm{Zn}$ possibly implies their short-term raised presence or bioavailability during the annual developmental cycle [46]. BCF criterion indicates hyperaccumulation for most of the metals in case of $C$. demersum and $S$. natans. The BCF apportionment clearly summarize $M$. aquaticum and $N$. nucifera to dissipate the PTE in their rhizosphere zone but the rootless $C$. demersum and $S$. natans concentrate them in their foliage parts $[115]$. 
The tissue concentration of nutrients and trace elements differ species wise but well correlate with ambient water and sediment media [116]. The biological sinks scavenge the deleterious proportions of nutrient supply from lakes preventing them from being overtaken by blooms. Even if slight phytoextraction of inorganics would have occurred physically compared to large scale quanta of the insitu media, still the biogenic calcification evidenced in the summers is capable of lowering them mediated via temperature, $\mathrm{pH}, \mathrm{HCO}_{3}{ }^{-}$and $\mathrm{Ca}$ changes [45]. Hence, a selective and scaled deweeding practice can thereby work wonders in lake management and restoration programmes [117].

\section{Conclusion and Recommendations}

A progressive urban expansion and associated activities have introduced substantial problems in the lake. Besides, the Dal is a shallow (1 m mean depth) urban recreational and tourist spot with crucial socio-economic reliance supporting $\sim 5$ lac population within $>10$ catchment to lake ratio. Since cultural eutrophication coincides with human pressures inside the inland surface waters, along the drainage basins and surrounding catchments as well, their evolution to dystrophy is certain yet manageable. The deteriorating water quality; ecological changes; eutrophication; reduced morphometric dimensions and volume holding; devaluing aesthetic, economic and recreational values; increased organic production and pollution are a cumulative product of denuded catchment leading to erosion and leaching; encroachment; diffuse garbage, sewage and city sewerage dumping; animal, human, agricultural and urban waste; silt loading and blockade of outflow channels; floating gardening and decomposition of biotic debris; unregulated tourism stress and roadway runoff. Another aspect of eutrophication process finds a complex interrelationship of contributing factors of climate, precipitation, basin morphology, hydrogeography of natural drainage and cultural factors. Monitoring the prevalent trophic status and other ecological conditions of an aquatic ecosystem is imperative for formulating conservation policies and action plan vital for its future sustenance, management and restoration. The study reveals the importance of effective monitoring program and appropriate management mechanism to attain and/or conform to desired water quality guidelines. The management of water resources aims at their sustainable use by protecting and improving both the quality and quantity while maintaining socioeconomic development.

Inspite of multiple anthropogenic stresses and catchment intervention, the low basin holding period due to semi-drainage type hydrology ensures a self-reclaimed homeostasis in nutrient and pollutant dissipation. Calcite co-precipitation and biological uptake reduce epilimnion ion concentrations considerably. Primary source of traces have anthropogenic origin but the priority pollutants remain below USEPA chronic CCC levels. The sediment zone corresponds to catchment character and land-use while its element profile conform their sink-selves. Sediment dredging is beneficial for insitu nutrient deloading only when exsitu inputs are delimited. Since macrophytes scavenge nutrients unselectively even at low loading rates to limit water quality degradation, their biomass harvesting post peak-growth phase will avoid nutrient and metal remobilisation. The present research assessment signifies the lake as a region of anthro-urban intensification in less than a century of progressive human history. The financial assistance provided under National Plan for Conservation of Aquatic Ecosystems (NPCA) is essential for imminent prevention of pollution, insitu leniency control and cleaning, catchment area treatment and lake-front improvement. Comprehensive management interventions employed to limit degradation and to revive its condition include sewage treatment and solid waste management, house boat sanitation, regulated catchment area and shoreline development, controlled dredging, selective and scaled manual-cum-mechanical deweeding, unblocking of clogged channels, construction of settling basin on Telbal nallah, law enforcement to remove and prevent encroachment, relocation of lake populace, etc. in order to improve the hydrology and ecology of the lake. Further portions of the study sanction ecomanagement of stressor human practices to avoid extreme eutrophication (hypertrophism) when $\mathrm{N}$ and $\mathrm{P}$ exceed 30 and $3 \mathrm{mgL}^{-1}$ respectively. Conclusively, the main lacustrine components contemporarily reflect 'euoecism' as a cooperative defensive mechanism for sustaining integral structure and function of the system. But once the hypertrophic limits are surpassed due to mismanagement or negligence detrimental 'dysoecism' shall prevail. 
Acknowledgements. The authors acknowledge Central Instrumentation Facility (CIF), Pondicherry University- 605014; Indian Institute of Technology and Management (IITM), Chennai- 600036; and Quality Control cum Leaf Tissue Analysis Lab, Sheri Kashmir Agricultural University of Science and Technology (SKAUST), Srinagar-191121 for facilitating lab and instrumentation services.

\section{References}

1. Kalff, J. (2002). Limnology: inland water ecosystems (Vol. 592). New Jersey: Prentice Hall.

2. Wetzel, R. G. (2001). Land-water interfaces: larger plants. Limnology, 3rd Edn., Academic Press, San Diego.

3. MEA, Millennium Ecosystem Assessment (2005). Ecosystems and Human Well-Being: Current State and Trends. Island Press, Washington, DC.

4. National Wetland Atlas: Jammu and Kashmir. (2010). SAC/RESA/AFEG/NWIA/ATLAS/16/2010, Space Applications Centre, ISRO, Ahmedabad, India, 176.

5. Pandit, A. K. (2002). Topical evolution of lakes in Kashmir Himalaya. Natural resources of western Himalaya. Valley Book House, Srinagar JEKK, 213-242.

6. Romshoo, S. A., \& Rashid, I. (2012). Assessing the impacts of changing land cover and climate on Hokersar wetland in Indian Himalayas. Arabian Journal of Geosciences, 7(1), 143-160.

7. Badar, B., Romshoo, S. A., \& Khan, M. A. (2012). Integrating biophysical and socioeconomic information for prioritizing watersheds in a Kashmir Himalayan lake: a remote sensing and GIS approach. Environmental monitoring and assessment, 185(8), 6419-6445.

8. Andersen, J. H., Axe, P., Backer, H., Carstensen, J., Claussen, U., Fleming-Lehtinen, V., \& Kubiliute, A. (2010). Getting the measure of eutrophication in the Baltic Sea: towards improved assessment principles and methods. Biogeochemistry, 106(2), 137-156.

9. USEPA. (2014). The Assessment and TMDL Tracking and Implementation System. National Summary of State Information. http://iaspub.epa.gov/waters10/attains_nation_cy.control\#total_assessed_waters.

10. WHO. (2006). Guidelines for drinking water Quality Vol. 1 Recommendations. 3rd ed. Geneva: World Health Organisation.

11. Hering, D., Borja, A., Carstensen, J., Carvalho, L., Elliott, M., Feld, C. K., \& Solheim, A. L. (2010). The European Water Framework Directive at the age of 10: a critical review of the achievements with recommendations for the future. Science of the total Environment, 408(19), 4007-4019.

12. Rashid, I., Romshoo, S. A., Amin, M., Khanday, S. A., \& Chauhan, P. (2016). Linking human-biophysical interactions with the trophic status of Dal Lake, Kashmir Himalaya, India. Limnologica-Ecology and Management of Inland Waters, 62, 84-96.

13. Sabah ul Solim, \& Wanganeo, A. (2008). Excessive phosphorus loading to Dal Lake, India: Implications for managing shallow eutrophic lakes in urbanized watersheds. International Review of Hydrobiology, 93(2), 148166.

14. Fazal, S., \& Amin, A. (2011). Impact of urban land transformation on water bodies in Srinagar City, India. Journal of environmental protection, 2(02), 142- 153.

15. Badar, B., Romshoo, S. A., \& Khan, M. A. (2013). Modelling catchment hydrological responses in a Himalayan Lake as a function of changing land use and land cover. Journal of earth system science, 122(2), 433-449.

16. Jan, D., Pandit, A. K., \& Kamili, A.N. (2013). Efficiency evaluation of three fluidised aerobic bioreactor based sewage treatment plants in Kashmir Valley. African Journal of Biotechnology, 12(17), 2224- 2233.

17. APHA,. (2005). APHA, AWWA, \& WEF. Standard methods for the examination of water and wastewater, $21^{\text {st }}$ edn., Washington, DC.

18. Morford, J.L., Emerson, S.R., Breckel, E.J., \& Kim, S.H. (2005). Diagenesis of oxyanions (V, U, Re, and Mo) in porewaters and sediments from a continental margin. Geochimica et cosmochimica Acta. 69, 5021 -5032.

19. Mazej, Z., \& Germ, M. (2009). Trace element accumulation and distribution in four aquatic macrophytes. Chemosphere, $74(5), 642-647$.

20. Parker, J. L., \& Bloom, N. S. (2005). Preservation and storage techniques for low-level aqueous mercury speciation. Science of the Total Environment, 337(1), 253-263.

21. U. S. Environmental Protection Agency. (1994). Method 200.7 : Determination of Metals and Trace Elements in Water and Wastes By Inductively Coupled Plasma - Atomic Emission Spectrometry, Revision 4.4, EMMC.

22. Matusiewicz, H. (2003). Wet digestion methods (Vol. 41). Elsevier: Amsterdam, Netherlands, 193-233. 
23. Ryan, J., Estefan, G., \& Rashid, A. (2001). Soil and Plant Analysis Laboratory Manual. International Center for Agricultural Research in the Dry Areas (ICARDA). Aleppo, Syria.

24. Gupta, P.K. (2004). Soil, Plant, Water and Fertilizer Analysis. Agro Botanica, Vyas Nagar, Bikaner, India.

25. Radojevic, M., \& Bashkin, V.N. (2006). Practical Environmental Analysis (2 ${ }^{\text {nd }}$ Ed).The Royal Society of Chemistry, Thomas Graham House, Science Park, Milton Road, Cambridge CB4 0 WF, UK.

26. Estefan, G., Sommer, R., \& Ryan, J. (2013). Methods of Soil, Plant and Water Analysis. International Center for Agricultural Research in the Dry Areas (ICARDA), Beirut, Lebanon.

27. Cook, C. D. (1996). Aquatic and Wetland Plants of India: A reference book and identification manual for the vascular plants found in permanent or seasonal fresh water in the subcontinent of India south of the Himalayas (Vol. 198548214). Oxford: Oxford University Press, 1-385.

28. Ghosh, S. K. (2005). Illustrated aquatic and wetland plants in harmony with mankind. Standard Literature, 1225.

29. Arshid, S., Wani, A. A., Ganie, A. H., \& Khuroo, A. A. (2011). On correct identification, range expansion and management implications of Myriophyllum aquaticum in Kashmir Himalaya, India. Check List, 7(3), 299-302.

30. Saison, C., Schwartz, C., \& Morel, J. L. (2004). Hyperaccumulation of metals by Thlaspi caerulescens as affected by root development and $\mathrm{Cd}-\mathrm{Zn} / \mathrm{Ca}-\mathrm{Mg}$ interactions. International Journal of phytoremediation, 6(1), 49-61.

31. Han, Y.M., Du, P.X., Cao, J.J., Posmentier, E.S. (2006). Multivariate analysis of heavy metal contamination in urban dusts of Xi'an, Central China. Science of the Total Environment, 355, 176-186.

32. Macias, C.G., Schifter, I., Lluch-Cota, D. B., Mendez-Rodriguez, L., \& Hernandez-Vazquez, S. (2006). Distribution, enrichment and accumulation of heavy metals in coastal sediments of Salina Cruz Bay, Mexico. Environmental Monitoring and Assessment, 118(1), 211-230.

33. Wei, B., \& Yang, L. (2010). A review of heavy metal contaminations in urban soils, urban road dusts and agricultural soils from China. Microchemical Journal, 94(2), 99-107.

34. Zhang, C., Qiao, Q., Piper, J. D., \& Huang, B. (2011). Assessment of heavy metal pollution from a Fesmelting plant in urban river sediments using environmental magnetic and geochemical methods. Environmental Pollution, 159(10), 3057-3070.

35. Raj, S. M., \& Jayaprakash, M. (2007). Distribution and enrichment of trace metals in marine sediments of Bay of Bengal, off Ennore, south-east coast of India. Environmental Geology, 56(1), 207-217.

36. MacDonald, D. D., Ingersoll, C. G., \& Berger, T. A. (2000). Development and evaluation of consensus-based sediment quality guidelines for freshwater ecosystems. Archives of environmental contamination and toxicology, 39(1), 20-31.

37. Maanan, M., Saddik, M., Maanan, M., Chaibi, M., Assobhei, O., \& Zourarah, B. (2015). Environmental and ecological risk assessment of heavy metals in sediments of Nador lagoon, Morocco. Ecological Indicators, 48, 616-626.

38. ANZECC/ARMCANZ. (2000). Australian and New Zealand guidelines for fresh and marine water quality. Australian and New Zealand Environment and Conservation Council and Agriculture and Resource Management Council of Australia and New Zealand, Canberra, 1-103.

39. Batley, G. E. (2000). Implications of the new ANZECC/ARMCANZ water quality guidelines for mining companies, In. Grundon, NJ and Bell, LC. In Proceedings of the Fourth Australian Workshop on Acid Mine Drainage, 221-229.

40. Wright, J. F., Sutcliffe, D. W., \& Furse, M. T. (2000). Assessing the biological quality of fresh waters: RIVPACS and other techniques. In Assessing the biological quality of fresh waters: RIVPACS and other techniques. Freshwater Biological Association.

41. Bunn, S. E., \& Davies, P. M. (2000). Biological processes in running waters and their implications for the assessment of ecological integrity. In Assessing the Ecological Integrity of Running Waters (pp. 61-70). Springer Netherlands.

42. Gupta, A., Ronghang, M., Kumar, P., Mehrotra, I., Kumar, S., Grischek, T., \& Knoeller, K. (2015). Nitrate contamination of riverbank filtrate at Srinagar, Uttarakhand, India: A case of geogenic mineralization. Journal of Hydrology, 531, 626-637.

43. de Jonge, V. N., Elliott, M., \& Orive, E. (2002). Causes, historical development, effects and future challenges of a common environmental problem: eutrophication. Hydrobiologia, 475(1), 1-19.

44. Bu, H., Meng, W., Zhang, Y., \& Wan, J. (2014). Relationships between land use patterns and water quality in the Taizi River basin, China. Ecological Indicators, 41, 187-197. 
45. Boyd, C. E., Tucker, C. S., \& Somridhivej, B. (2016). Alkalinity and hardness: critical but elusive concepts in aquaculture. Journal of the World Aquaculture Society, 47(1), 6-41.

46. Wiik, E., Bennion, H., Sayer, C. D., Davidson, T. A., McGowan, S., Patmore, I. R., \& Clarke, S. J. (2015). Ecological sensitivity of marl lakes to nutrient enrichment: evidence from Hawes Water, UK. Freshwater Biology, 60(11), 2226-2247.

47. Njenga, J. W. (2004). Comparative studies of water chemistry of four tropical lakes in Kenya and India. Asian journal of water, environment and pollution, 1(1, 2), 87-97.

48. Singh, S. P., \& Singh, B. P. (2010). Geothermal evolution of the evaporite-bearing sequences of the Lesser Himalaya, India. International Journal of Earth Sciences, 99(1), 101-108.

49. Jeelani, G., \& Shah, A. Q. (2006). Geochemical characteristics of water and sediment from the Dal Lake, Kashmir Himalaya: constraints on weathering and anthropogenic activity. Environmental Geology, 50(1), 1223.

50. Berzas Nevado, J. J., Rodríguez Martín-Doimeadios, R. C., Guzmán Bernardo, F. J., Jiménez Moreno, M., Ortega Tardío, S., Sánchez-Herrera Fornieles, M. M., \& Doncel Pérez, A. (2009). Integrated pollution evaluation of the Tagus River in Central Spain. Environmental monitoring and assessment, 156(1), 461-477.

51. Yu, Y., Song, J., Li, X., \& Duan, L. (2012). Geochemical records of decadal variations in terrestrial input and recent anthropogenic eutrophication in the Changjiang Estuary and its adjacent waters. Applied Geochemistry, $27(8), 1556-1566$.

52. Feichtinger, F., Smidt, S., \& Klaghofer, E. (2002). Water and nitrate fluxes at a forest site in the North Tyrolean Limestone Alps. Environmental Science and Pollution Research, 9(2), 31.

53. Hayakawa, A., Ikeda, S., Tsushima, R., Ishikawa, Y., \& Hidaka, S. (2015). Spatial and temporal variations in nutrients in water and riverbed sediments at the mouths of rivers that enter Lake Hachiro, a shallow eutrophic lake in Japan. Catena, 133, 486-494.

54. Srebotnjak, T., Carr, G., de Sherbinin, A., \& Rickwood, C. (2012). A global Water Quality Index and hotdeck imputation of missing data. Ecological Indicators, 17, 108-119.

55. Michard, G., Sarazin, G., Jézéquel, D., Albéric, P., \& Ogier, S. (2001). Annual budget of chemical elements in a eutrophic lake, Aydat lake (Puy-de-Dôme), France. Hydrobiologia, 459(1), 27-46.

56. Müller, B., Meyer, J. S., \& Gächter, R. (2016). Alkalinity regulation in calcium carbonate-buffered lakes. Limnology and Oceanography, 61(1), 341-352.

57. Olsen, S., Jeppesen, E., Moss, B., Özkan, K., Beklioğlu, M., Feuchtmayr, H., \& Søndergaard, M. (2014). Factors influencing nitrogen processing in lakes: an experimental approach. Freshwater Biology, 60(4), 646-662.

58. Nnaji, C. C., \& Agunwamba, J. C. (2014). Quality assessment of water receiving effluents from crude oil flow stations in Niger Delta, Nigeria. Water and Environment Journal, 28(1), 104-113.

59. Xu, Y., Xie, R., Wang, Y., \& Sha, J. (2014). Spatio-temporal variations of water quality in Yuqiao Reservoir Basin, North China. Frontiers of Environmental Science 83 Engineering, 9(4), 649-664.

60. Belkhiri, L., \& Narany, T. S. (2015). Using multivariate statistical analysis, geostatistical techniques and structural equation modeling to identify spatial variability of groundwater quality. Water Resources Management, 29(6), 2073-2089.

61. Ouma, H., \& Mwamburi, J. (2014). Spatial variations in nutrients and other physicochemical variables in the topographically closed Lake Baringo freshwater basin (Kenya). Lakes 8 Reservoirs: Research ES Management, 19(1), 11-23.

62. Chon, H. S., Ohandja, D. G., \& Voulvoulis, N. (2012). The role of sediments as a source of metals in river catchments. Chemosphere, 88(10), 1250-1256.

63. Moiseenko, T. I., Gashkina, N. A., \& Dinu, M. I. (2016). Enrichment of Surface Water by Elements: Effects of Air Pollution, Acidification and Eutrophication. Environmental Processes, 3(1), 39-58.

64. FAO, Food and agriculture organization. (2010). The wealth of waste: the economics of wastewater use in agriculture. Water Reports, (35).

65. Tchobanoglous, G., Burton F. L., \& Stensel H. D. (2003). Wastewater engineering: treatment and reuse. Metcalf \& Eddy Inc., New York, NY: McGraw Hill.

66. Markich, S. J., Brown, P. L., Batley, G. E., Apte, S. C., \& Stauber, J. L. (2001). Incorporating metal speciation and bioavailability into water quality guidelines for protecting aquatic ecosystems. Australasian Journal of Ecotoxicology, 7(2), 109-122.

67. Li, D., Huang, D., Guo, C., \& Guo, X. (2015). Multivariate statistical analysis of temporal-spatial variations in water quality of a constructed wetland purification system in a typical park in Beijing, China. Environmental monitoring and assessment, 187(1), 4219. DOI 10.1007/s10661-014-4219-2 
68. Najar, I. A., \& Khan, A. B. (2012). Assessment of water quality and identification of pollution sources of three lakes in Kashmir, India, using multivariate analysis. Environmental Earth Sciences, 66(8), 2367-2378.

69. Downing, J. A., Cole, J. J., Middelburg, J. J., Striegl, R. G., Duarte, C. M., Kortelainen, P., \& Laube, K. A. (2008). Sediment organic carbon burial in agriculturally eutrophic impoundments over the last century. Global Biogeochemical Cycles, 22(1), 1- 10.

70. Wagner, B., Lotter, A. F., Nowaczyk, N., Reed, J. M., Schwalb, A., Sulpizio, R., \& Zanchetta, G. (2009). A 40,000-year record of environmental change from ancient Lake Ohrid (Albania and Macedonia). Journal of Paleolimnology, 41(3), 407-430.

71. Knoll, L. B., Vanni, M. J., Renwick, W. H., \& Kollie, S. (2014). Burial rates and stoichiometry of sedimentary carbon, nitrogen and phosphorus in Midwestern US reservoirs. Freshwater biology, 59(11), 2342-2353.

72. Schaller, J., Vymazal, J., \& Brackhage, C. (2013). Retention of resources (metals, metalloids and rare earth elements) by autochthonously/allochthonously dominated wetlands: a review. Ecological Engineering, 53, 106114.

73. Ammar, R., Kazpard, V., Wazne, M., El Samrani, A. G., Amacha, N., Saad, Z., \& Chou, L. (2015). Reservoir sediments: a sink or source of chemicals at the surface water-groundwater interface. Environmental monitoring and assessment, $187(9), 579$.

74. Urban, N. R., Brezonik, P. L., Baker, L. A., \& Sherman, L. A. (2009). Sulfate reduction and diffusion in sediments of Little Rock Lake, Wisconsin. Limnology and Oceanography, 39(4), 797-815.

75. Gudasz, C., Bastviken, D., Steger, K., Premke, K., Sobek, S., \& Tranvik, L. J. (2010). Temperature-controlled organic carbon mineralization in lake sediments. Nature, 466(7305), 478-481.

76. de Vicente, I., Guerrero, F., \& Cruz-Pizarro, L. (2010). Chemical composition of wetland sediments as an integrator of trophic state. Aquatic Ecosystem Health $\& 3$ Management, 13(1), 99-103.

77. Heathcote, A. J., \& Downing, J. A. (2012). Impacts of eutrophication on carbon burial in freshwater lakes in an intensively agricultural landscape. Ecosystems, 15(1), 60-70.

78. Tranvik, L. J., Downing, J. A., Cotner, J. B., Loiselle, S. A., Striegl, R. G., Ballatore, T. J., \& Kortelainen, P. L. (2009). Lakes and reservoirs as regulators of carbon cycling and climate. Limnology and Oceanography, 54(6part2), 2298-2314.

79. Min, K., Kang, H., \& Lee, D. (2011). Effects of ammonium and nitrate additions on carbon mineralization in wetland soils. Soil Biology and Biochemistry, 43(12), 2461-2469.

80. Garland, J. L., Mackowiak, C. L., \& Zabaloy, M. C. (2010). Organic waste amendment effects on soil microbial activity in a corn-rye rotation: Application of a new approach to community-level physiological profiling. Applied Soil Ecology, 44(3), 262-269.

81. Allison, S. D., Czimczik, C. I., \& Treseder, K. K. (2008). Microbial activity and soil respiration under nitrogen addition in Alaskan boreal forest. Global Change Biology, 14(5), 1156-1168.

82. Elser, J. J., Andersen, T., Baron, J. S., Bergström, A. K., Jansson, M., Kyle, M., \& Hessen, D. O. (2009). Shifts in lake N: P stoichiometry and nutrient limitation driven by atmospheric nitrogen deposition. science, 326(5954), 835-837.

83. Abell, J. M., Özkundakci, D., \& Hamilton, D. P. (2010). Nitrogen and phosphorus limitation of phytoplankton growth in New Zealand lakes: implications for eutrophication control. Ecosystems, 13(7), 966-977.

84. Canavan, R. W., Slomp, C. P., Jourabchi, P., Van Cappellen, P., Laverman, A. M., \& Van den Berg, G. A. (2006). Organic matter mineralization in sediment of a coastal freshwater lake and response to salinization. Geochimica et Cosmochimica Acta, 70(11), 2836-2855.

85. Smolders, A. J. P., Lamers, L. P. M., Lucassen, E. C. H. E. T., Van der Velde, G., \& Roelofs, J. G. M. (2006). Internal eutrophication: how it works and what to do about it - a review. Chemistry and ecology, 22(2), 93-111.

86. Jing, L.D., xi Wu, C., tong Liu, J., guang Wang, H., \& yi Ao, H. (2013). The effects of dredging on nitrogen balance in sediment-water microcosms and implications to dredging projects. Ecological Engineering, 52, 167174.

87. Jing, L., Liu, X., Bai, S., Wu, C., Ao, H., \& Liu, J. (2015). Effects of sediment dredging on internal phosphorus: A comparative field study focused on iron and phosphorus forms in sediments. Ecological Engineering, 82, 267-271.

88. Turner, A., Millward, G. E., \& Le Roux, S. M. (2004). Significance of oxides and particulate organic matter in controlling trace metal partitioning in a contaminated estuary. Marine Chemistry, 88(3), 179-192.

89. Selig, U., \& Schlungbaum, G. (2003). Characterisation and quantification of phosphorus release from profundal bottom sediments in two dimictic lakes during summer stratification. Journal of Limnology. 62(2), 151-162. 
90. Lopes, M. L., Rodrigues, A. M., \& Quintino, V. (2014). Ecological effects of contaminated sediments following a decade of no industrial effluents emissions: The Sediment Quality Triad approach. Marine pollution bulletin, $87(1), 117-130$.

91. Wali, A., Kawachi, A., Bougi, M. S. M., Dhia, H. B., Isoda, H., Tsujimura, M., \& Ksibi, M. (2015). Effects of metal pollution on sediments in a highly saline aquatic ecosystem: case of the Moknine Continental Sebkha (Eastern Tunisia). Bulletin of environmental contamination and toxicology, 94(4), 511-518.

92. Chandrasekaran, A., Ravisankar, R., Harikrishnan, N., Satapathy, K. K., Prasad, M. V. R., \& Kanagasabapathy, K. V. (2015). Multivariate statistical analysis of heavy metal concentration in soils of Yelagiri Hills, Tamilnadu, India-Spectroscopical approach. Spectrochimica Acta Part A: Molecular and Biomolecular Spectroscopy, 137, 589-600.

93. Bastami, K. D., Neyestani, M. R., Shemirani, F., Soltani, F., Haghparast, S., \& Akbari, A. (2015). Heavy metal pollution assessment in relation to sediment properties in the coastal sediments of the southern Caspian Sea. Marine pollution bulletin, 92(1), 237-243.

94. Iqbal, J., Tirmizi, S. A., \& Shah, M. H. (2013). Statistical apportionment and risk assessment of selected metals in sediments from Rawal Lake (Pakistan). Environmental monitoring and assessment, 185(1), 729-743.

95. Ji, Y., Zhang, J., Li, R., Pan, B., Zhang, L., \& Chen, X. (2015). Distribution and partitioning of heavy metals in sediments of the Xinjiang River in Poyang Lake Region, China. Environmental Progress Es Sustainable Energy, 34(3), 713-723.

96. Sany, S. B. T., Hashim, R., Rezayi, M., Salleh, A., \& Safari, O. (2014). A review of strategies to monitor water and sediment quality for a sustainability assessment of marine environment. Environmental Science and Pollution Research, 21(2), 813-833.

97. Yuan, Z., Taoran, S., Yan, Z., \& Tao, Y. (2014). Spatial distribution and risk assessment of heavy metals in sediments from a hypertrophic plateau lake Dianchi, China. Environmental monitoring and assessment, 186(2), 1219-1234.

98. Paramasivam, K., Ramasamy, V., \& Suresh, G. (2015). Impact of sediment characteristics on the heavy metal concentration and their ecological risk level of surface sediments of Vaigai river, Tamilnadu, India. Spectrochimica Acta Part A: Molecular and Biomolecular Spectroscopy, 137, 397-407.

99. Kissoon, L. T., Jacob, D. L., Hanson, M. A., Herwig, B. R., Bowe, S. E., \& Otte, M. L. (2013). Macrophytes in shallow lakes: Relationships with water, sediment and watershed characteristics. Aquatic Botany, 109, 39-48.

100. Gottschall, N., Boutin, C., Crolla, A., Kinsley, C., \& Champagne, P. (2007). The role of plants in the removal of nutrients at a constructed wetland treating agricultural (dairy) wastewater, Ontario, Canada. Ecological Engineering, 29(2), 154-163.

101. Ismail, Z., Othman, S. Z., Law, K. H., Sulaiman, A. H., \& Hashim, R. (2014). Comparative Performance of Water Hyacinth ( Eichhornia crassipes) and Water Lettuce (Pista stratiotes) in Preventing Nutrients Build-up in Municipal Wastewater. CLEAN - Soil, Air, Water, 43(4), 521-531.

102. El-Otify, A. M. (2015). Evaluation of the physicochemical and chlorophyll-a conditions of a subtropical aquaculture in Lake Nasser area, Egypt. Beni-Suef University Journal of Basic and Applied Sciences, 4(4), 327-337.

103. Hasler, C. T., Butman, D., Jeffrey, J. D., \& Suski, C. D. (2016). Freshwater biota and rising pCO2? Ecology Letters, 19(1), 98-108.

104. McElarney, Y., Rasmussen, P., Foy, R., \& Anderson, N. (2010). Response of aquatic macrophytes in Northern Irish softwater lakes to forestry management; eutrophication and dissolved organic carbon. Aquatic Botany, 93(4), 227-236.

105. Shaltout, K. H., Galal, T. M., \& El-Komi, T. M. (2014). Biomass, nutrients and nutritive value of Persicaria salicifolia Willd. in the water courses of Nile Delta, Egypt. Rendiconti Lincei, 25(2), 167-179.

106. Chen, X., Yang, X., Dong, X., \& Liu, E. (2013). Environmental changes in Chaohu Lake (southeast, China) since the mid 20th century: The interactive impacts of nutrients, hydrology and climate. Limnologica Ecology and Management of Inland Waters, 43(1), 10-17.

107. Udeigwe, T. K., Teboh, J. M., Eze, P. N., Hashem Stietiya, M., Kumar, V., Hendrix, J., Kandakji, T. (2015). Implications of leading crop production practices on environmental quality and human health. Journal of Environmental Management, 151, 267-279.

108. Liu, J. L., Liu, J. K., Anderson, J. T., Zhang, R., \& Zhang, Z. M. (2014). Potential of aquatic macrophytes and artificial floating island for removing contaminants. Plant Biosystems - An International Journal Dealing with all Aspects of Plant Biology, 150(4), 702-709. 
109. Sarwar, N., Saifullah, Malhi, S. S., Zia, M. H., Naeem, A., Bibi, S., \& Farid, G. (2010). Role of mineral nutrition in minimizing cadmium accumulation by plants. Journal of the Science of Food and Agriculture, 90, 925-937.

110. Cotner, J. B., Kenning, J., \& Scott, J. T. (2009). The microbial role in littoral zone biogeochemical processes: why Wetzel was right. Verh Int Ver Limnol, 30, 981-984.

111. Quilliam, R. S., Van Niekerk, M. A., Chadwick, D. R., Cross, P., Hanley, N., Jones, D. L., Oliver, D. M. (2015). Can macrophyte harvesting from eutrophic water close the loop on nutrient loss from agricultural land? Journal of Environmental Management, 152, 210-217.

112. Wang, C. Y., Sample, D. J., Day, S. D., \& Grizzard, T. J. (2015). Floating treatment wetland nutrient removal through vegetation harvest and observations from a field study. Ecological Engineering, 78, 15-26.

113. Zheng, Y., Wang, X. C., Ge, Y., Dzakpasu, M., Zhao, Y., \& Xiong, J. (2015). Effects of annual harvesting on plants growth and nutrients removal in surface-flow constructed wetlands in northwestern China. Ecological Engineering, 83, 268-275.

114. Sistla, S. A., Appling, A. P., Lewandowska, A. M., Taylor, B. N., \& Wolf, A. A. (2015). Stoichiometric flexibility in response to fertilization along gradients of environmental and organismal nutrient richness. Oikos, $124(7), 949-959$.

115. Harguinteguy, C. A., Cirelli, A. F., \& Pignata, M. L. (2014). Heavy metal accumulation in leaves of aquatic plant Stuckenia filiformis and its relationship with sediment and water in the Suquía river (Argentina). Microchemical Journal, 114, 111-118.

116. Amari, T., Ghnaya, T., Debez, A., Taamali, M., Youssef, N. B., Lucchini, G., \& Abdelly, C. (2014). Comparative Ni tolerance and accumulation potentials between Mesembryanthemum crystallinum (halophyte) and Brassica juncea: metal accumulation, nutrient status and photosynthetic activity. Journal of plant physiology, 171(17), 1634-1644.

117. Novak, P. A., \& Chambers, J. M. (2014). Investigation of nutrient thresholds to guide restoration and management of two impounded rivers in south-western Australia. Ecological Engineering, 68, 116-123. 